UNIVERSIDADE DE SÃO PAULO

FACULDADE DE ZOOTECNIA E ENGENHARIA DE ALIMENTOS

MÔNICA FERREIRA ACCORSI

Avaliação de embriões bovinos cultivados in vitro na presença de ácidos graxos e sua sobrevivência pós-criopreservação

PIRASSUNUNGA - SP 
MÔNICA FERREIRA ACCORSI

\title{
Avaliação de embriões bovinos cultivados in vitro na presença de ácidos graxos e sua sobrevivência pós-criopreservação
}

\author{
Dissertação apresentada à Faculdade de Zootecnia e \\ Engenharia de Alimentos da Universidade de São \\ Paulo, como parte dos requisitos para obtenção do \\ Título de Mestre em Zootecnia.
}

Área de Concentração: Qualidade e Produtividade Animal

Orientador: Prof. Dr. Flávio Vieira Meirelles

PIRASSUNUNGA - SP

2008 
Dados Internacionais de Catalogação na Publicação

Serviço de Biblioteca e Informação da Faculdade de Zootecnia e Engenharia de Alimentos da Universidade de São Paulo

Accorsi, Mônica Ferreira
A172a Avaliação de embriões bovinos cultivados in vitro na presença de ácidos graxos e sua sobrevivência póscriopreservação / Mônica Ferreira Accorsi. --

Pirassununga, 2008.

$77 \mathrm{f}$.

Dissertação (Mestrado) -- Faculdade de Zootecnia e Engenharia de Alimentos - Universidade de São Paulo. Departamento de Ciências Básicas.

Área de Concentração: Qualidade e Produtividade Animal.

Orientador: Prof. Dr. Flávio Vieira Meirelles.

1. Ácidos graxos 2. Embriões bovinos in vitro 3. Criopreservação. I. Título. 
Dedico à meu pai, meu exemplo de vida $e$ meu maior orgulho, Edner Accorsi, que mesmo não estando mais presente fisicamente, foi o maior incentivador para a realização deste trabalho. 


\section{AGRADECIMENTOS}

À minha mãe, meu amor maior e meu porto seguro, pela compreensão, incentivo e paciência nos momentos difíceis.

À minha família linda, que sempre unida me ensinou como o amor, o companheirismo, a dedicação e o respeito são essenciais para qualquer ser humano crescer e ser feliz.

À Faculdade de Zootecnia e Engenharia de Alimentos - FZEA, pela realização do mestrado.

Ao professor e orientador, Dr. Flávio Vieira Meirelles, pela oportunidade dada e por acreditar que era possível a realização desta, mesmo com todas as barreiras que surgiram no decorrer da realização do trabalho.

\section{À Fundação de Amparo à Pesquisa do Estado de São Paulo (FAPESP),} pelo financiamento do projeto PIPE.

À Vitrogen, empresa pela qual dediquei anos importantes da minha vida, e que tive em retribuição, aprendizado e oportunidade de crescimento. Yeda, obrigada por tudo.

Aos grandes amigos de Vitrogen, que me ajudaram e muito nesta caminhada, e em especial ao Danie1, que sem ele com certeza metade dos processos não teriam sido realizados.

Ao Fernando Pupim, por aceitar o convite sem pestanejar, para realizar as transferências dos embriões para as receptoras.

À todos os integrantes do Laboratório de Morfofisiologia Molecular e Desenvolvimento (LMMD), em especial a Giovana Krempel Fonseca Merighe, a Gi, pela ajuda constante e por me "socorrer" sempre em todas as etapas do desenvolvimento do trabalho. 
À Andréa Brasil Vieira José, por passar toda a sua experiência com os ácidos graxos sem nenhuma barreira, e com toda a paciência do mundo foi me fazendo entender o funcionamento e importância destes.

À minha irmã Renata, por aturar o convívio diário e os momentos dificeis durante esses anos.

Às minhas amigas para toda a vida, por respeitar os momentos de estudo e pela alegria e incentivo sempre necessários.

Ao Léo, meu companheiro, pela paciência, apoio e pelos "nãos" aceitos com tanto carinho durante o período de execução desta.

Aos meus "filhos" de quatro patas, que constantemente estavam ao meu lado durante os estudos dando todo o apoio que só um cachorro sabe dar.

À todas as pessoas que participaram direta ou indiretamente deste trabalho, meus sinceros agradecimentos. 


\section{SUMÁRIO}

1. INTRODUÇÃO

01

\section{REVISÃO BIBLIOGRÁFICA}

2.1. Histórico da produção in vitro de embriões ......................... 04

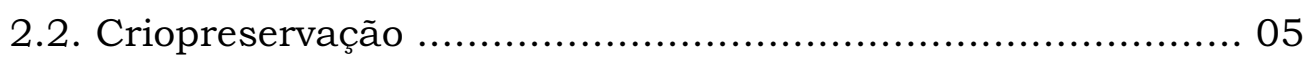

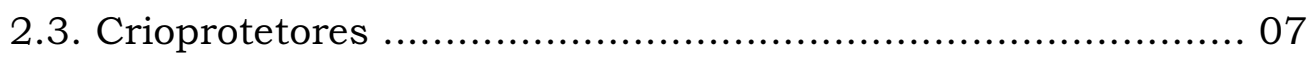

2.4. Comparação entre embriões produzidos in vivo $\mathrm{x}$ in vitro ..... 09

2.5. Lipídeos, membranas e o processo de criopreservação .......... 11

2.6. Ácidos graxos (CLA, LA, EPA, DHA) ……........................ 14

2.7. Cultivo in Vitro com SFB (Soro Fetal Bovino) ..................... 23

2.8. Atmosfera gasosa de $5 \%$ x $20 \%$ de oxigênio ....................... 26

2.9. Viabilidade embrionária (taxa de prenhez) ....................... 27

\section{PRODUÇÃO DE EMBRIÕES IN VITRO COM OU SEM ADIÇÃO DOS DIFERENTES ÁCIDOS GRAXOS EM ATMOSFERA DE 5\% $\mathrm{CO}_{2}$ EM AR}

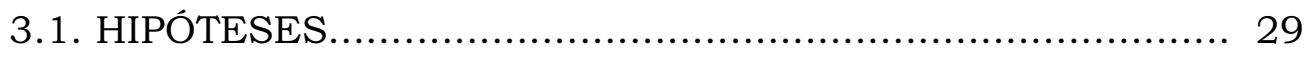

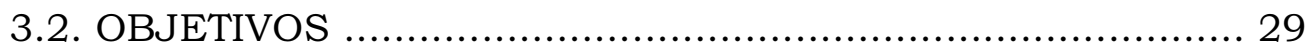

3.3. JUSTIFICATIVA ….................................................. 30

3.4. MATERIAL E MÉTODOS

3.4.1. Local do experimento .......................................... 30

3.4.2. Produção in vitro de embriões .............................. 31

3.4.3. Análise qualitativa dos embriões - Coloração Hoechst ............................................................. 32

3.4.4. Análise do conteúdo total de lipídeos nos embriões Coloração Nile Red 32

3.4.5. Criopreservação de embriões ................................ 33

3.4.6. Re-expansão dos embriões pós-descongelação: sobrevivência in vitro 34 
3.4.7. Transferência dos embriões para receptoras: sobrevivência in vivo .......................................................... 34

3.4.8. Diagnóstico de gestação ........................................ 35

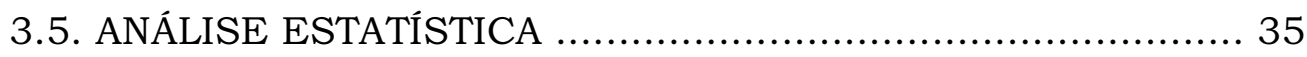

3.6. DELINIAMENTO EXPERIMENTAL …............................. 37

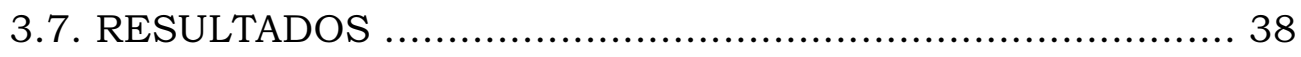

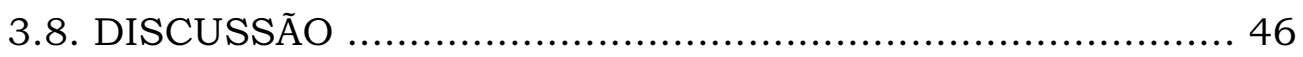

3.9. RESUMO DOS RESULTADOS ….................................. 52

3.10. CONCLUSÃO E PERSPECTIVAS ................................... 53

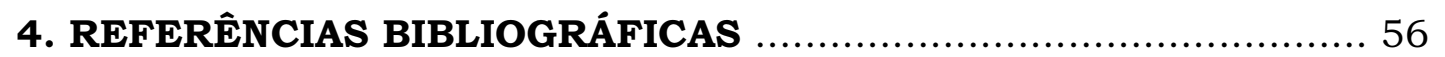




\section{RESUMO}

\section{ACCORSI, M.F. Avaliação de embriões bovinos cultivados in vitro na} presença de ácidos graxos e sua sobrevivência pós-criopreservação. 2008. 77 f. Dissertação (Mestrado) - Faculdade de Zootecnia e Engenharia de Alimentos, Universidade de São Paulo, Pirassununga, 2008.

Tendo em vista a possibilidade de que a adição de ácidos graxos ao meio de cultivo embrionário aumente a sobrevivência ao congelamento, a proposta deste trabalho foi avaliar o efeito da adição de quatro ácidos graxos isoladamente ao meio de cultivo, dois do grupo ômega 6 (ácido linoléico e ácido linoléico conjugado) e dois do grupo ômega 3 (ácido eicosapentaenóico e ácido docosahexaenóico), na produção de embriões, no número de células, na quantidade de lipídeos, na taxa de re-expansão da blastocele após 48 horas de cultivos pós-descongelamento, na taxa de eclosão pósdescongelamento e na taxa de gestação. Para tal, os oócitos bovinos colhidos de ovários de vacas abatidas foram maturados, fecundados e cultivados in vitro em atmosfera de $5 \% \mathrm{CO}_{2} \mathrm{em}$ ar, à $38,8^{\circ} \mathrm{C}$ e máxima umidade. No cultivo, foi adicionado isoladamente um destes ácidos graxos, e foram avaliadas a taxa de clivagem, e a produção de embriões no sétimo e oitavo dia de cultivo. No sétimo dia, os blastocistos expandidos foram congelados com 1,5M de etileno glicol. Eles permaneceram nesta solução por 9 minutos antes de serem envasados e seguirem para a maquina de congelamento numa taxa de resfriamento de $0,5^{\circ} \mathrm{C} / \mathrm{minuto}$ até chegarem à temperatura de $-32^{\circ} \mathrm{C}$. Dos embriões que foram congelados, alguns seguiram para o descongelamento e voltaram para o cultivo in vitro para avaliação da reexpansão e taxa de eclosão pós-descongelamento. Outros foram transferidos para receptoras sincronizadas para avaliação da taxa de gestação. Outros grupos de embriões permaneceram até o oitavo dia de cultivo e foram corados com Hoechst 33342 para contagem dos núcleos, e corados com Nile Red para avaliação do conteúdo total de lipídeos. Em geral, a adição isolada de ácidos graxos do grupo ômega 6 (CLA e LA) na produção in vitro de embriões bovinos aumentou a taxa de sobrevivência ao congelamento (criotolerância), no entanto, não houve um aumento no número de células, nem diferença no conteúdo total de lipídeos nos embriões analisados. A taxa de gestação também não diferiu estatisticamente entre os grupos testados in vivo, porém foi observado um aumento de 200\% na taxa de gestação dos embriões cultivados na presença de CLA. Novos estudos devem ser desenvolvidos para comprovar o efeito do aumento da criotolerância e melhorias nas taxas de gestações dos embriões, além de estudos da composição de lipídeos nos embriões e membranas.

Palavras chaves: ácidos graxos, embriões bovinos in vitro, criopreservação. 


\begin{abstract}
ACCORSI, M.F. Assessment of bovine embryos grown in vitro in the presence of fatty acids and their survival after cryopreservation. 2008.
\end{abstract}

77 f. Dissertation - Faculdade de Zootecnia e Engenharia de Alimentos, Universidade de São Paulo, Pirassununga, 2008.

In the view of the possibility that the addition of fatty acids in the embryo growing medium increase the survival rate after cryopreservation, this study was proposed to evaluate the effect of the addition of four fatty acids in culture medium, two of the omega 6 group (linoleic acid and conjugated linoleic acid) and two of the omega 3 group (eicosapentainoic acid and docosahexaenoic acid), in the rate of production of blastocysts, blastocyst cell number, blastocyst amount of lipids, re-expansion of blastocele rate after 48 hours of culture post-thaw, post-thaw hatching rate and pregnancy rate. The oocytes obtained by punction of slaughterhouse cows were matured in vitro, fertilized in vitro and cultured in vitro in an atmosphere of $5 \% \mathrm{CO}_{2}$ in air, to $38,8^{\circ} \mathrm{C}$ and maximum moisture. Fatty acids were supplemented individually and cleavage rate and production of embryos in the seventh and eighth days of culture were assessed. On seventh day, the expanded blastocysts were frozen with $1.5 \mathrm{M}$ of ethylene glycol. They remained in this solution for nine minutes before introduction in a straw followed and then in a freezing machine with a chilling rate of $0,5^{\circ} \mathrm{C} /$ minute until temperature of $-32^{\circ} \mathrm{C}$. Frozen embryos were then divide in two groups: one was thawed and returned to in vitro culture in other to assess the reexpansion and post-hatching rate, and other was transferred to synchronized recipients to assess the pregnancy rate. Another unfreezed group of embryos were stained with Hoechst 33342 for counting the nuclei, or stained with Nile Red to estimate the lipids contents. In general, the addition of fatty acids omega 6 group (LA and CLA) increased the survival rate to the freezing (cryotolerancy), however, there was no increase in the number of cells, or difference in the lipids contents. In the CLA treated embryos, the pregnancy rate of the freezed embryos did not differ from groups tested in vivo, but there was a $200 \%$ increase in the pregnancy rate. Further studies should be developed to prove the improvements in the rates of pregnancies of omega 6 treated embryos, besides a study of the composition of lipids of embryos and membranes should be conducted.

Keywords: fatty acids, in vitro bovine embryos, cryopreservation. 


\section{INTRODUÇÃO}

A criopreservação de embriões facilita e sofistica o comércio de animais principalmente provenientes de linhagens de alto padrão genético e de grande expressão econômica e científica (DE BEM et al., 1995; LÔBO et al, 1996).

A produção em larga escala de embriões bovinos produzidos in vitro é dependente da produção de um grande número de embriões de alta qualidade. Embora a produção in vitro de embriões bovinos seja muito difundida e empregada há algumas décadas, a eficiência da técnica ainda é pouco satisfatória, e apenas cerca de $40 \%$ dos oócitos maturados in vitro atingem o estágio de blastocisto. Mais importante, quando estes blastocistos obtidos in vitro são submetidos à criopreservação, a eficiência média do processo baixa ainda mais e a taxa de gestação pós-descongelamento é menor que $10 \%$ apresentando variações de resultados.

A alta sensibilidade dos embriões derivados in vitro para criopreservação pode ser justificada por diferenças morfológicas, celulares, metabólicas e fisiológicas entre as duas categorias de embriões (LEIBO e LOSKOTOFF, 1993; RIZOS et al., 2002, 2008).

Tendo em vista que embriões produzidos in vivo são criopreservados com sucesso, possivelmente, a baixa eficiência do método está relacionada às condições sub-ótimas de cultivo, desde a maturação até o desenvolvimento embrionário in vitro (NIEMANN, 1995; SEIDEL, 2006; LONERGAN et al., 2006).

Um dos problemas patentes do desenvolvimento embrionário in vitro é a síntese ou o acúmulo excessivo de lipídios no citoplasma dos embriões induzido pela presença de soro fetal bovino (SFB) e outros componentes no meio de cultura (SHAMSUDDIN e RODRIGUEZ-MARTINEZ, 1994; ABE et al., 1999; PEREIRA et al., 2008a,2008b). É descrito que o excesso lipídico pode causar alteração na fluidez e função da membrana plasmática ou danos ao citoesqueleto e às junções célula-célula. Visando contornar estes efeitos 
prejudiciais, pesquisadores procuraram desenvolver sistemas de cultivo livre de soro e de ácidos graxos onde o soro fetal é substituído pela albumina bovina fração livre de ácidos graxos (FERGUSON e LEESE, 1999) ou meios suplementados com agentes antioxidantes como a Vitamina E que diminuem o impacto do oxigênio sobre os lipídeos (REIS et al., 2002).

A remoção do SFB dos meios de cultivo é uma alternativa inviável, que encerra uma grande dificuldade se associado à diminuição da taxa de oxigênio, quando se considera a produção em grande escala de embriões bovinos destinados à criopreservação, devido, principalmente, ao tempo necessário para retirar as células do cumulus, separadamente para o conjunto de complexos cumulus-oócito de cada doadora e seus acasalamentos.

Uma alternativa para tentar diminuir o acúmulo de lipídeos nos embriões e influenciar pouco no processo como os embriões são produzidos, é a utilização dos ácidos linoléicos conjugados, também conhecidos como ácidos ruminóicos. Eles são um grupo de isômeros posicionais e geométricos do ácido linoléico produzido a partir da biohidrogenação bacteriana no rúmen (KEPLER et al., 1966). A partir do estudo pioneiro de $\mathrm{Ha}$ e colaboradores (PARIZA et al., 2001) demonstrando o efeito inibitório do ácido linoléico em neoplasias epidérmicas induzidas pelo benzeno-pireno em camundongos, diversos outros trabalhos têm salientado os efeitos biológicos e fisiológicos do uso de CLA, especialmente os isômeros cis-9; trans-11 (c-9;t11) e trans-10;cis-12 (t-10;c-12), onde, dentre os efeitos fisiológicos observados estão a diminuição da "massa" gordurosa do corpo com aumento da "massa" magra em murinos (PARK et al., 1999), redução do acúmulo lipídico durante a diferenciação de adipócitos humanos e murinos (BROMN et al., 2001; EVANS et al., 2001) e redução da síntese de gordura do leite em vacas em lactação que ingeriram CLA (BAUMGARD et al., 2002).

Mais especificamente ficou demonstrado que a adição de uma mistura de isômeros de CLA ou a forma $t$-10;c-12 per-se inibe a expressão do mRNA de genes envolvidos na lipogênese durante a diferenciação dos adipócitos (GRANLUND et al., 2003). Finalmente os ácidos graxos como os ômegas 3 e 
6, por exemplo, estão sendo estudados mais cuidadosamente em cultivos de células in vitro. Um trabalho realizado no Brasil aplicando estes suplementos demonstrou que a modificação do conteúdo de ácidos graxos altera o padrão de expressão gênica de leucócitos humanos (VERLENGIA et al., 2004).

Os ácidos graxos e lipídios são contribuintes essenciais para a integridade estrutural, funcional e metabólica do embrião pré-implantação. Apesar desta importância, os ácidos graxos têm sido negligenciados como constituintes dos meios de cultivo dos embriões sendo a sua contribuição, positiva ou não, amplamente ignorada.

Um estudo sobre a adição de ácido linoléico conjugado (CLA) ao meio de cultivo de embriões bovinos (PEREIRA et al., 2004) demonstrou um efeito positivo no aumento das taxas de sobrevivência embrionária póscriopreservação. Entretanto, os autores relatam seus resultados utilizando critérios morfológicos de re-expansão da blastocele pós-descongelamento, sem evidência de maior viabilidade in vivo do grupo tratado em relação aos embriões gerados em meio padrão. Esse mesmo grupo mostrou que a suplementação com CLA em meios de cultura na presença de SFB diminui a deposição de lipídeos no citoplasma dos embriões durante o cultivo in vitro e melhorou significativamente a resistência do embrião produzido in vitro à congelação. Neste trabalho foi avaliada da taxa de re-expansão da blastocele após descongelamento, e medida a quantidade de lipídeos (PEREIRA et al., 2008a).

Existe, portanto, a necessidade de caracterizar a contribuição dos ácidos graxos ao desenvolvimento embrionário in vitro, assim como assegurar que sua presença exerce um efeito benéfico no embrião. Esta dissertação teve o propósito de investigar os efeitos da adição de quatro ácidos graxos: ácido linoléico conjugado (CLA), ácido linoléico (LA), ácido eicosapentaenóico (EPA) e ácido docosahexaenóico (DHA) isoladamente aos meios de cultivo para produção de embriões. Para tanto, foram analisadas a taxa de desenvolvimento ao estádio de blastocisto e a qualidade dos mesmos (estimada pelo número de células), a concentração de lipídeos estimada pelo corante Nile Red, a viabilidade pós-descongelamento medida pela re- 
expansão da blastocele e a taxa de gestação aos 90 dias pós-transferência de embriões em receptoras sincronizadas.

\section{REVISÃO BIBLIOGRÁFICA}

\subsection{Histórico da Produção in vitro de Embriões}

$\mathrm{Na}$ década de 40, os primeiros estudos de fecundação in vitro eram feitos em ouriços do mar, pela facilidade de observação do processo, pois nos invertebrados marinhos a fecundação ocorre externamente ao sistema reprodutor da fêmea.

Somente na segunda metade do século XX, com o desenvolvimento da química, houve uma melhora na qualidade da produção de meios, e a embriologia passou por progressos significativos, com profundos reflexos no sucesso de coleta e cultivo de embriões.

Os primeiros trabalhos experimentais em embriologia de mamíferos foram realizados em coelhos, tendo em vista suas características biológicas favoráveis, como o tamanho relativamente grande do oócito, o que facilita a manipulação, e a ovulação induzida pelo acasalamento, fato de elevado conveniência para determinação da idade precisa dos embriões.

Foram os estudos desenvolvidos por Austin (1951) e Chang (1951) sobre capacitação espermática que permitiram grandes avanços no entendimento dos mecanismos básicos da fecundação. O marco na história da FIV se deu na década de 50, quando foi registrado o primeiro nascimento, a partir de experimentos com fecundação in vitro em coelhos (CHANG, 1959). A partir daí, até o final dos anos 70, vários outros relatos da obtenção de FIV seguida de nascimentos de filhotes saudáveis foram registrados.

Em 1978, Steptoe e Edwards relatam o nascimento do primeiro bebê nascido de fecundação in vitro em humano.

$\mathrm{Na}$ década de 80 , foi publicado o nascimento do primeiro bezerro sadio produzido a partir de FIV, sendo que os oócitos foram maturados in vivo e 
fecundados com sêmen fresco (BRACKETT et al., 1982). Em 1986, a primeira prenhez de embriões produzidos in vitro com o uso de sêmen congelado (PARRISH et al., 1986). Os primeiros nascimentos obtidos de embriões bovinos produzidos totalmente in vitro (maturação, fecundação e cultivo) foram obtidos por LU et al. (1987).

No Brasil, em 1993 a equipe da UNESP de Jaboticabal obteve as primeiras prenhezes de embriões bovinos produzidos totalmente in vitro (WATANABE et al., 1993). Neste mesmo ano, a equipe do CENARGEMEMBRAPA obteve duas prenhezes de embriões zebuínos (PEIXER et al., 1994).

O nascimento de bezerros Nelore PO (pura origem), mediante a maturação, fecundação e cultivo in vitro, foi obtido pela equipe da USP de Ribeirão Preto em 1996 (DE AZAMBUJA et al., 1996), assim como as primeiras prenhezes a partir de embriões bovinos produzidos in vitro após o processo de vitrificação (WATANABE et al., 1996).

Atualmente, o Brasil possui o maior rebanho bovino comercial do mundo, com cerca de 196 milhões de animais, e apresenta-se em posição de destaque na produção mundial de embriões, particularmente pela expansão no uso da fecundação in vitro. Segundo dados da Sociedade Brasileira de Tecnologia de Embriões (SBTE), no ano de 2006 no Brasil foram transferidos 196.663 embriões produzidos in vitro, isso corresponde a $48 \%$ dos embriões

produzidos e transferidos no mundo, contra 69.886 produzidos in vivo, que corresponde a $18 \%$ da produção mundial.

\subsection{Criopreservação}

A criobiologia é o estudo do efeito das baixas temperaturas sobre as células biológicas e as conseqüências das alterações de fase da água no curso do resfriamento e reaquecimento.

No processo de congelamento a cristalização se dará primeiro no meio extracelular, levando as células a um processo de desidratação em decorrência da diferença osmótica gerada no sistema (MAZUR, 1977), onde 
ocorre a expulsão da água intracelular associada ao influxo de íons e conseqüentemente perda da turgescência da célula (MAZUR, 1984).

Todos os protocolos são desenhados para proteger o embrião contra a formação de cristais de gelo intracelular durante o congelamento e a recristalização durante o aquecimento. Para prevenir a formação de cristais, a água intracelular é substituída por crioprotetores permeáveis e os embriões desidratados relativamente por razões de congelamento lento (PALASZ et al., 1996).

A vitrificação segundo Fahy et al. (1984) é a solificação de um líquido produzida pela extrema elevação na viscosidade durante a congelação, ou seja, um processo químico pelo qual uma solução concentrada solidifica durante o resfriamento sem cristalizar, formando o vitreo. Durante a vitrificação não são formados cristais de gelo, mas as mudanças osmóticas são freqüentemente mais severas do que no congelamento e aumenta os efeitos tóxicos nas células embrionárias (KUWAYAMA et al., 1994; DOBRINKY, 1996).

Até agora, a comparação direta entre vitrificação e congelamento tem conduzidos a resultados diferentes dependendo do método (KAIDI et al., 2001).

No descongelamento ocorre um influxo de água para as células podendo provocar uma ruptura da membrana plasmática e/ou dos compartimentos membranosos intracelulares e, alterações nas biomembranas, que acarretam mudanças nos constituintes presentes na bicamada lipídica (DROBNIS et al., 1993).

Embora o conteúdo lipídico pareça afetar a sensibilidade e conseqüentemente a sobrevivência dos embriões criopreservados (ABE et al., 2002), há outros fatores básicos tal como a razão congelamento e aquecimento, tamanho e estágio de desenvolvimento do embrião, propriedades osmóticas e toxicidade dos crioprotetores que sabidamente tem um efeito no congelamento (PALASZ et al., 1996).

Em 1971, Whittingham relatou a criopreservação de embriões de camundongos no estágio de mórula. Um ano depois, Wilmut e Rowson (1973) 
relataram a primeira prenhez oriunda de transferência de embriões congelados e descongelados bovinos.

O primeiro bezerro nascido de embriões bovinos produzidos totalmente in vitro e criopreservados e descongelados foi relatado por FUKUDA et al. (1990).

Embriões de animais domésticos e silvestres que têm sido congelados com sucesso incluem vacas, ovelhas, cabras, cavalos, suínos, coelhos, gatos, babuínos, camundongos, macacos e humanos (RALL, 1992; TROUNSEN e MOHR, 1983; MAZUR et al., 2008). Entretanto, a viabilidade pósdescongelamento varia entre as espécies.

Há mais de 25 anos, pesquisas básicas e aplicadas dentro da área de criopreservação de oócitos e embriões de mamíferos têm focado em simplificar os processos de congelamento e descongelamento. One Step, diluição direta do crioprotetor, vitrificação, congelamento rápido; aumentando a viabilidade pós-descongelamento e desenvolvimentos efeitos de soluções crioprotetoras que não requerem o uso de substâncias de origem biológica (JOLY et al., 1992; LEIBO, 1986, 1992, 2008; LEIBO e LOSKUTOFF, 1993; MASSIP et al., 1993; SEIDEL et al., 1990).

Diversas hipóteses são apresentadas para explicar as causas da baixa criotolerância dos embriões produzidos in vitro. As condições estáticas da maioria dos protocolos de cultivo e as substâncias que compõem estes meios induzem o aparecimento de alterações morfológicas e ultra-estruturais nos embriões, que são detectadas somente quando estes são comparados àqueles desenvolvidos sob condições in vivo (MASSIP et al., 1995). Entre outras, as divergências traduzem-se no número de células, no grau de compactação entre os blastômeros, no metabolismo lipídico do embrião e/ou na integridade e permeabilidade das membranas plasmáticas.

\subsection{Crioprotetores}

Desde a descoberta da ação crioprotetora do glicerol por POLGE et al. (1949), vários compostos têm sido testados. Os crioprotetores são 
necessários nas soluções de congelamento por prevenir a célula dos danos causados no congelamento e descongelamento.

Segundo a classificação seguida no mundo todo, os crioprotetores são divididos em agentes crioprotetores intracelulares e agentes crioprotetores extracelulares (MERYMAN, 1971; SEIDEL, 1984). Os intracelulares baseiamse na redução da temperatura de congelação do meio, conferindo maior período para remoção da água intracelular durante o resfriamento prévio à congelação da água. Os extracelulares são substâncias não permeáveis à membrana (de elevado peso molecular) e possuem ação estabilizadora e reparadora da membrana.

Os três maiores grupos são: os de baixo peso molecular e permeáveis (etileno glicol, DMSO, glicerol, metanol), os de baixo peso molecular e não permeáveis (glicose, galactose, sacarose) e o grupo dos de alto peso molecular e impermeáveis (polivinilpirrolidona, álcool polivinil). A presença de moléculas de baixo peso molecular e permeáveis são absolutamente necessárias, pois elas substituem a água intracelular nas células do embrião antes do congelamento lento controlado, reduzindo as mudanças no volume das células e minimizando a formação de cristais de gelo dentro das células dos embriões (PALASZ et al., 1996).

A criopreservação com a técnica controlada envolve o uso de crioprotetores isoladamente (etileno glicol ou glicerol ou propanodiol). Já o congelamento rápido ou vitrificação envolve o uso de misturas de crioprotetores assim como glicerol e etileno glicol, glicerol e propanodiol ou propanodiol e etileno glicol e combinados com sacarose, trealose ou galactose (LEIBO e ODA, 1993; RAYOS et al., 1992).

Neste trabalho, foi utilizada a técnica "padrão" com etileno glicol, congelamento lento aplicando uma curva já bem padronizada e com bons resultados com embriões produzidos in vivo (LEIBO, 1986; MASSIP et al., 1989; NIEMANN, 1995). Neste processo de congelamento lento, uma etapa, o seeding, é considerada essencial para a sobrevivência embrionária e este passo tem que ser executado cuidadosamente (LEIBO, 2008; de PAZ et al., 1994). 
O etileno glicol pode facilmente se difundir nas células embrionárias sem causar danos celulares grosseiros (VOELKEL e HU, 1992). A baixa toxicidade do etileno foi demonstrada por Sommerfeld e Niemann (1999) que testaram concentrações de 1,8 a $8,9 \mathrm{M}$, e que também usaram o etileno glicol como o único crioprotetor para blastocistos bovinos. A razão de eclosão in vitro depois do congelamento convencional foi similar ao controle, enquanto os vitrificados foram menores. Voelkel e Hu (1992) mostraram a eficiência do etileno glicol na concentração de $1.5 \mathrm{M}$ como crioprotetor de embriões bovinos. A Razão de prenhez ficou entre 50 e $70 \%$ para embriões in vivo (NIEMANN, 1995).

O método com etileno glicol é de fácil uso por técnicas de inseminação artificial ou transferência de embriões, e isto é largamente aceito (MASSIP et al., 2001).

A mais recente versão do "one step" foi empregar o uso de um crioprotetor de alta permeabilidade, assim como o etileno glicol, e a transferência dos embriões dentro do útero da receptora logo após o descongelamento (SUZUKI et al., 1990). Este crioprotetor penetra na membrana da célula muito rapidamente, e embriões congelados/descongelados sofrem pouquíssimo choque osmótico quando transferidos diretamente dentro do meio isotônico. $\mathrm{O}$ processo de transferência direta permite a transferência ao útero da receptora da palheta que foi descongelada sem a necessidade de banhos sucessivos nos embriões. Isto substancialmente simplifica o processo de transferência, reduz o tempo necessário e elimina a necessidade de treinamento de pessoal e equipamentos especializados.

\subsection{Comparação entre embriões produzidos in vivo $\mathrm{x}$ in vitro}

A qualidade do embrião antes da congelação afeta diretamente a sobrevivência após a descongelação, portanto, o sistema de cultivo in vitro e o método de congelação estão relacionados e ambos afetam a viabilidade do embrião. 
Métodos padronizados de criopreservação que produzem altas taxas de sobrevivência de embriões derivados in vivo, normalmente resultam em baixa taxa de sobrevivência para os derivados in vitro que são mais sensiveis ao resfriamento e criopreservação (LEIBO e LOSKUTOFF, 1993; POLLARD e LEIBO, 1993; HASLER et al., 1995).

Os fatores que afetam a eficiência da criopreservação são a origem dos embriões (se é in vivo ou in vitro) e o estágio de desenvolvimento destes (MASSIP et al., 2001). Comparativo in vivo e in vitro mostram notável diferença na morfologia, metabolismo, e qualidade do embrião com considerações ao número de células e viabilidade ao congelamento (SHAMSUDDIN e RODRIGUEZ-MARTINEZ, 1994; MASSIP et al., 1995; ABE et al., 1999; RIZOS et al., 2008; MOORE et al., 2007).

A sobrevivência dos embriões produzidos in vitro congelados $\mathrm{e}$ descongelados pode ser afetada pela: idade do embrião, estágio de desenvolvimento embrionário, qualidade do embrião, crioprotetor, $\mathrm{pH}$ do meio de congelamento, processo de congelamento e pelo sistema de cultivo em que são desenvolvidos os embriões (HASLER, 1997).

Do ponto de vista morfológico, a qualidade dos embriões produzidos in vitro é inferior à dos produzidos in vivo, aumentando a susceptibilidade às injúrias (KHURAMA e NIEMANN, 2000a) decorrentes dos efeitos tóxicos e osmóticos dos crioprotetores, como a formação de cristais de gelo (VAJTA et al., 1997; POLLARD e LEIBO, 1994).

Os in vitro apresentam uma coloração do citoplasma mais escura e densidade mais baixa (LEIBO et al., 1993; POLLARD e LEIBO, 1994; ABE et al., 1999) devido ao acúmulo de lipídeos (ABB EL RAZEK et al., 2000), um espaço perivitelínico maior e com vesiculações, uma população menor de microvilos, reduzidas conexões intercelulares e vacúolos nos trofoblastos (KHURANA \& NIEMANN 2000b; THOMPSON, 2000), enquanto os in vivo, apresentam-se mais claros e homogêneos, com densidade maior, um espaço perivitelínico estreito com numerosas microvilosidades que se dispões continuamente ao longo da membrana plasmática e muitas junções intercelulares. Estas diferenças são possivelmente as que conferem aos 
embriões in vitro uma má tolerância à criopreservação (POLLARD e LEIBO, 1993; FAIR et al., 2001; RIZOS et al., 2002).

\subsection{Lipideos, membranas e o processo de criopreservação}

Os lipídeos têm papel significante no estoque de energia, na estrutura celular e podem modificar as propriedades físicas e a função metabólica das membranas biológicas (KIM et al., 2001).

A membrana vista ao microscópio, é uma camada fina altamente estruturada que mede cerca de $10 \mathrm{~nm}$ de espessura e é constituída por uma dupla camada fosfolipídica.

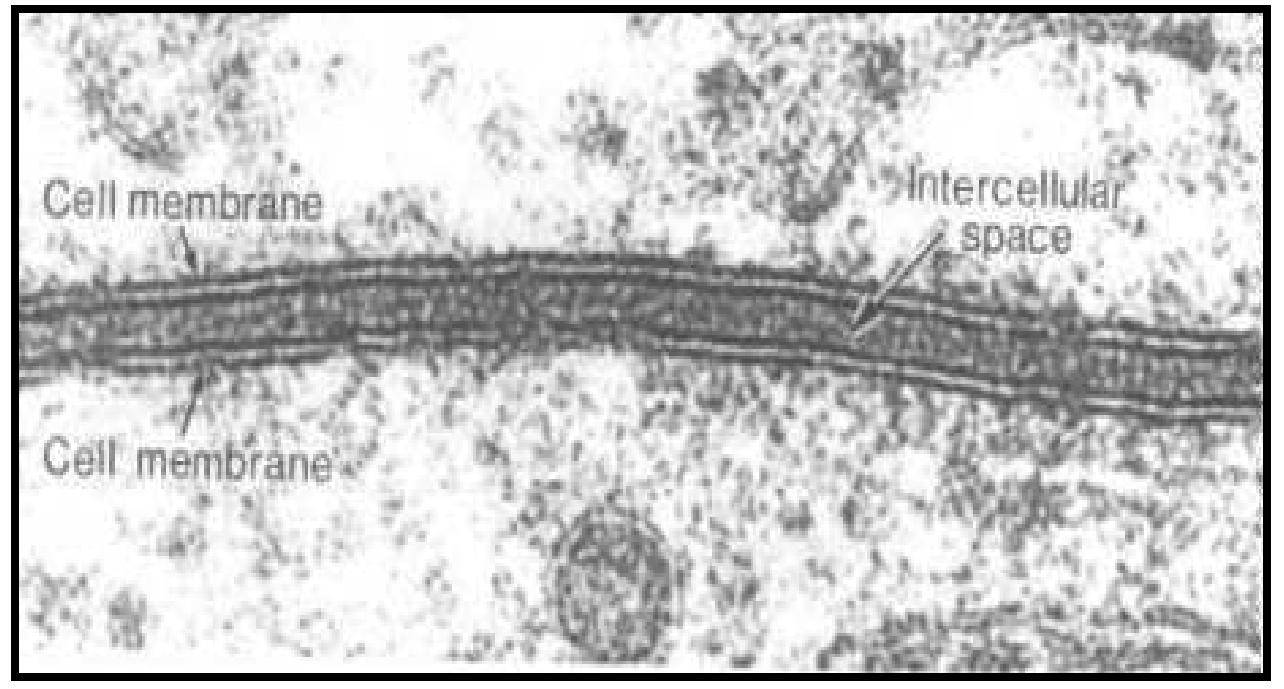

Figura 1. Eletromicrografia mostrando as membranas plasmáticas e o espaço intercelular.

A sua constituição lipoprotéica determinará seu comportamento durante o resfriamento ou à baixas temperaturas. Quanto mais alta a temperatura e quanto maior o número de insaturações mais fluida fica a membrana. À baixas temperaturas a conformação tridimensional dos canais da membrana se alteram e a membrana fica menos fluida. Aparentemente as células regulam a fluidez da membrana ajustando os tipos de ácidos graxos que são incorporados nela. Os lipídeos quando refrigerados, tornam-se 
endurecidos e quebradiços, podendo a integridade e a permeabilidade das membranas serem afetadas durante o resfriamento. Essas alterações físicoquímicas das membranas causarão alterações na dinâmica da água e nas concentrações intra e extracelulares durante a criopreservação (MORRIS e CLARK, 1987).

A membrana citoplasmática é a organela mais sensivel às baixas temperaturas (ARAV et al., 1996). As propriedades físicas da membrana são influenciadas pela composição de lipídeos e reguladas em resposta a fatores do ambiente, temperatura ou dieta (GUR e HARWOOD, 1991).

Uma perturbação na fluidez, estrutura e função da membrana plasmática causada pela peroxidação de lipídeos pode reduzir a permeabilidade da água e dos agentes crioprotetores, diminuindo a tolerância do embrião ao estresse do congelamento e descongelamento. Segundo Tarin et al. (1993), a tolerância do embrião de camundongo ao estresse do congelamento e descongelamento pode ser modificada por incubação dos embriões na presença de estimuladores e inibidores de peroxidação de lipídeos de membrana (apotransferina e ascorbato), sendo este efeito mais evidente em embriões criopreservados com a técnica do congelamento lento. A taxa de sobrevivência dos embriões descongelados passa de 66,9\% (controle) para 82,7\% (apotransferina) e 86,4\% (ascorbato). Embriões in vitro são mais sensiveis ao resfriamento e congelamento provavelmente devido a diferentes razões entre lipídeos e proteínas nos dois tipos de embriões (LEIBO e LOKUTOFF 1993; POLLARD e LEIBO, 1993).

O conteúdo lipídico de oócitos e embriões é um importante parâmetro que liga a qualidade à criotolerância. O conteúdo lipídico e o acúmulo de gotas pode ser influenciado pelo meio de cultura onde são desenvolvidos os oócitos e os embriões (ABE et al., 2002; LONERGAN et al., 2003; PEREIRA et al., 2008a; REIS et al., 2005; RIZOS et al., 2003, 2008).

A maioria dos lipídeos intracelulares de oócitos e embriões são os triacilgliceróis (FERGUNSON e LEESE, 1999) e a minoria das outras classes (fosfolipídeos e colesterol). Entretanto, enquanto os triacilgliceróis representam 40-50\% da massa de lipídeos total em embriões bovinos in vivo, in vitro eles podem atingir $88 \%$ da massa. Isso porque a concentração 
permanece estável nos embriões in vivo do estágio de 2 células até o estágio de blastocisto, enquanto os in vitro a reserva de triacilgliceróis pode duplicar no estágio de blastocisto em embriões expostos a cultura com soro fetal bovino (CHARPIGNY et al., 2003).

O excesso lipídico pode causar alteração na fluidez e função da membrana plasmática ou danos ao citoesqueleto e às junções célula-célula e também está associado a mitocôndrias imaturas, pequenos e menos numerosos microvilos (ABE et al., 2002; REIS et al., 2005; RIZOS et al., 2003; PEREIRA et al., 2008a).

Embora seja conhecido que as gotas lipídicas citoplasmáticas dos embriões são uma fonte de energia e que contêm produtos metabólicos e elementos estruturais, parece que elas não são essenciais para o desenvolvimento do embrião nos estágios iniciais de clivagem (USHIJIMA et al., 1999), ou que os embriões são capazes de sintetizar lipídeos adicionais. As vesículas de lipídeos dentro do citoplasma têm um estreito arranjo espacial com o retículo endoplasmático do embrião (HYTTEL e NIEMANN, 1990), e eles ajudam a promover a nutrição das células, assim como modificações nas propriedades físicas e função da membrana plasmática da célula (STUBBS e SMITH, 1984).

Recentemente estudos demonstraram que a remoção do lipídeo intracelular por centrifugação aumenta a tolerância à criopreservação dos embriões de suínos in vitro (NAGASHIMA et al., 1994,1995) e bovinos (LEIBO et al., 1995; USHIJIMA et al., 1999, 2004; ABE et al., 2002), mas a transferência destes embriões resulta em baixas taxas de prenhez sugerindo que o estoque de lipídeos herdado maternalmente interfere na sobrevivência pós- transferência (DIEZ et al., 1996, 2001), e esta perda pode estar relacionada a perturbação e localização subcelular das organelas quando os embriões são delipidados. Já gatos domésticos não apresentaram diferenças significativas na sobrevivência in vitro entre os embriões delipidados e controle (KARJA et al., 2006).

Resultados da equipe de Pereira et al. (2008a), mostram que a integridade pós-descongelação e a taxa re-expansão em embriões cultivados com SFB contendo CLA $t-10, c-12$ foram melhor que os obtidos a partir de 
meios definidos sem SFB, embora os embriões destes últimos apresentam menor acúmulo de lipídeos. A direta incorporação do CLA poliinsaturado dentro da membrana do embrião durante a cultura pode contribuir para um aumento da fluidez da membrana (nível de insaturação). A redução do conteúdo dos triacilgliceróis induzida por ele durante a cultura do embrião pode contribuir para o aumento da resistência do embrião a criopreservação.

\section{6. Ácidos graxos (LA, CLA, EPA e DHA)}

Os lipídeos não são apenas fonte de nutrientes para as células, eles têm papel importante na regulação das propriedades físicas e função das membranas biológicas, interação célula-célula, proliferação celular e transporte (SATA et al., 1999).

O ácido linoléico, ácido linoléico conjugado, ácido eicosapentaenóico e o ácido docosahexaenóico, respectivos, LA, CLA, EPA e DHA, são lipídeos bioativos, ou seja, são capazes de ter efeitos além daqueles esperados pela sua contribuição nutricional e energética. Os ácidos graxos poliinsaturados (PUFAS) são aqueles que possuem duas ou mais duplas ligações, e podem ser classificados em n-3 e n-6 baseado na localização da última dupla relativa com o terminal metil da molécula (Figura 02).

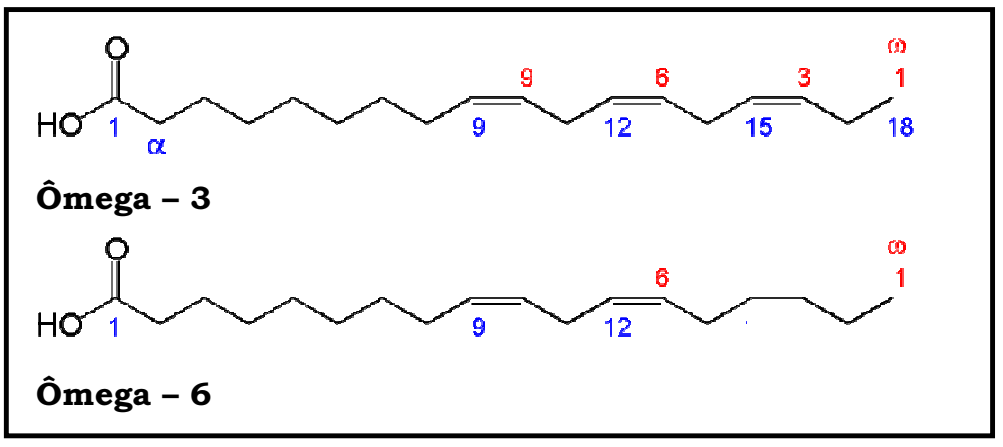

Figura 2. Exemplo de um ácido graxo poliinsaturado ômega 3 e um ômega 6.

Os n-3 e n-6 são definidos como essenciais por não poderem ser sintetizados pelos organismos, e são precursores de moléculas sinalizadoras com efeitos opostos, que modulam a composição dos microdomínios da 
membrana, sinalização de receptores e expressão de genes (SCHMITZ e ECKER, 2008).

Os $\underline{\text { n-6 }}$ (' $\Omega$ ) são importantes reguladores das funções celulares, na formação das membranas celulares, no correto funcionamento do sistema imunológico e no processo inflamatório. O LA (ácido linoléico, 18:2 n-6), o CLA (ácido linoléico conjugado, 18:2 n-6) e o AA (ácido araquidônico, 20:4 n6) são representantes deste grupo.

Os n-3 (' $\Omega$ 3) são derivados de óleos marinhos, e os seus representantes mais conhecidos são o ácido docosahexaenóico (DHA 22:6 n3) e o ácido eicosapentaenóico (EPA, 20:5 n-3). Eles apresentam propriedades como antiinflamatória, antitrombótica, vasodilatadora, parecem modular as prostaglandinas (LOMBARDO e CHICCO, 2006; SCHMITZ e ECKER, 2008), afetam o sistema de defesa e reparo, o ciclo celular, a apoptose, a sintese de DNA, fatores de transcrição e a expressão de genes (VERLENGIA et al., 2004).

Após entrar nas células com o auxilio de proteínas, os ácidos graxos podem ser oxidados para gerar energia, armazenados como triacilgliceróis ou usados na síntese de membranas.

Todos os ácidos graxos são derivados do ácido palmítico. Na cadeia n3, o precursor é o ácido alfa linolênico (ALA), e dos n-6 é o ácido linoléico (LA). O caminho para a sintese dos dois ômegas utiliza a mesma enzima, a delta-6-desaturase, e esta é vital para a conservação de ALA, EPA e DHA. A competição existe entre as famílias n-3 e n-6 para o metabolismo, onde o excesso de um causa uma diminuição da conversão do outro. A figura 3 ilustra a via de produção de cada um dos ácidos graxos utilizados neste trabalho. 


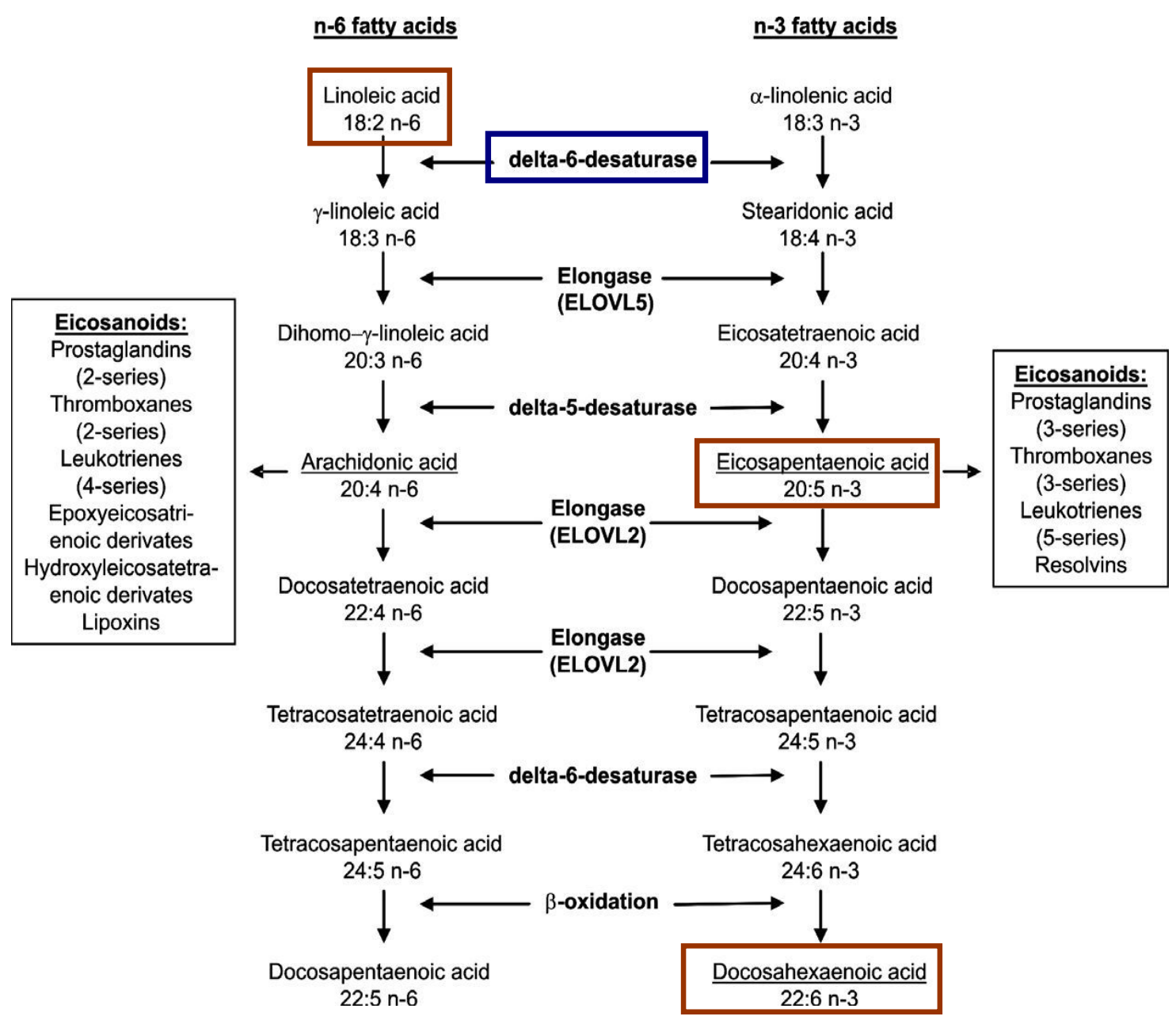

Figura 3. Metabolismo ácido graxo $n-3$ e n-6 (modificado a partir de SCHMITZ e ECKER, 2008).

Os n-3 e n-6 são armazenados na forma esterificada nos fosfolipídeos dos folhetos citosólico da célula e membranas das organelas ou em corpos lipídicos ligados à glicídeos neutros e aos fosfolipídeos polares (SCHMITZ e ECKER, 2008). Isto fica melhor ilustrado na figura 4. 


\section{$\underline{n-3}$ and $n-6$ fatty acid storage and release}

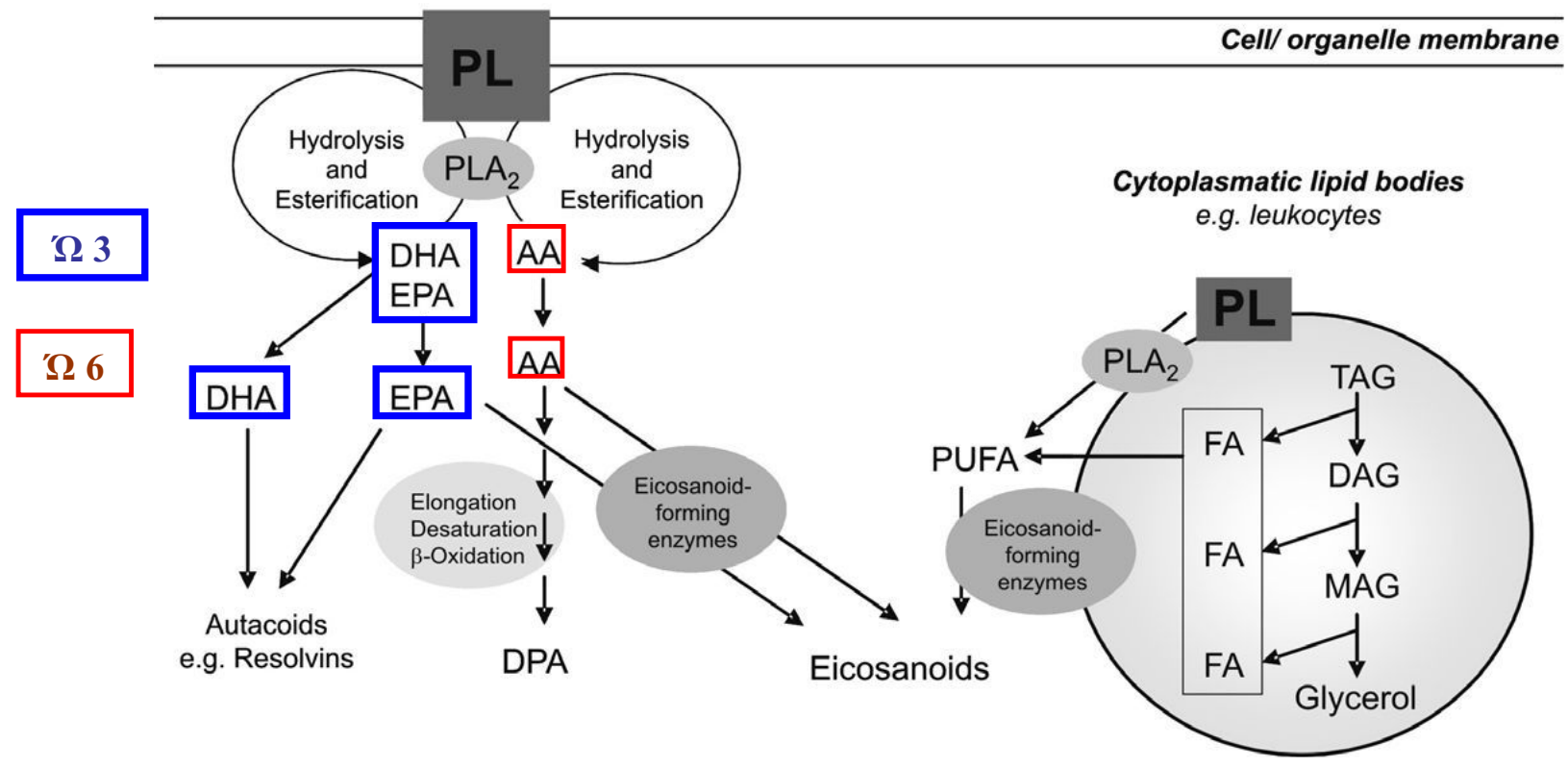

Figura 4. Os $\Omega 3$ e $\Omega 6$ são estocados nos fosfolipídeos das membranas e corpos lipídicos, e são liberados pela PLA2. AA, ácido aracdônico; DAG, diacilglicerol; DHA, ácido docosahexaenóico; DPA, ácido docosapentaenóico; EPA, ácido eicosapentaenóico; FA, ácido graxo; MAG, monoacilglicerol; PL, fosfolipídeo; PLA2, fosfolipase A2; PUFA, ácido graxo poliinsaturado; TAG, triacilglicerol (modificado a partir de SCHMITZ e ECKER, 2008).

Os ácidos graxos são liberados dos fosfolipídeos das membranas celulares e dos adipócitos pela enzima fosfolipase $\mathrm{A}_{2} \quad\left(\mathrm{PLA}_{2}\right)$, e são posteriormente metabolizados em eicosanóides e outros autacóides. Os eicosanóides derivados do ácido araquidônico (AA) são mais pró-ativos, enquanto EPA (n-3) são inibitórios do ponto de vista da reação inflamatória.

A lipólise é a quebra dos ácidos graxos estocados no tecido adiposo pela ação da enzima lípase sensível a hormônio (HSL), Eles estão estocados na forma de triacilglicerídeos, isto é, três ácidos graxos para cada molécula de glicerol (Figura 3). Quando a célula precisa de energia, a HSL degrada os triglicerídeos liberando-os na corrente sangüínea e assim os ácidos graxos são transportados pela proteína albumina, a fim de serem utilizados pelas células através da $\beta$-oxidação gerando energia, $\mathrm{CO}_{2}$ e água. O ácido graxo entra na célula e vai para a mitocôndria como Acetil-Coa graxo com o auxilio da carnitina, pois a membrana mitocondrial interna é impermeável a Acetil Coa . A oxidação destes é uma seqüência repetitiva de reações que produzem 
moléculas de Acetil-Coa que se transformam em citrato para sair da mitocôndria, corpos cetônicos e liberam energia. O mecanismo ocorre principalmente na matriz mitocondrial. Cada volta do ciclo de $\beta$-oxidação produz um NADH, um FADH2 e um Acetil-Coa.

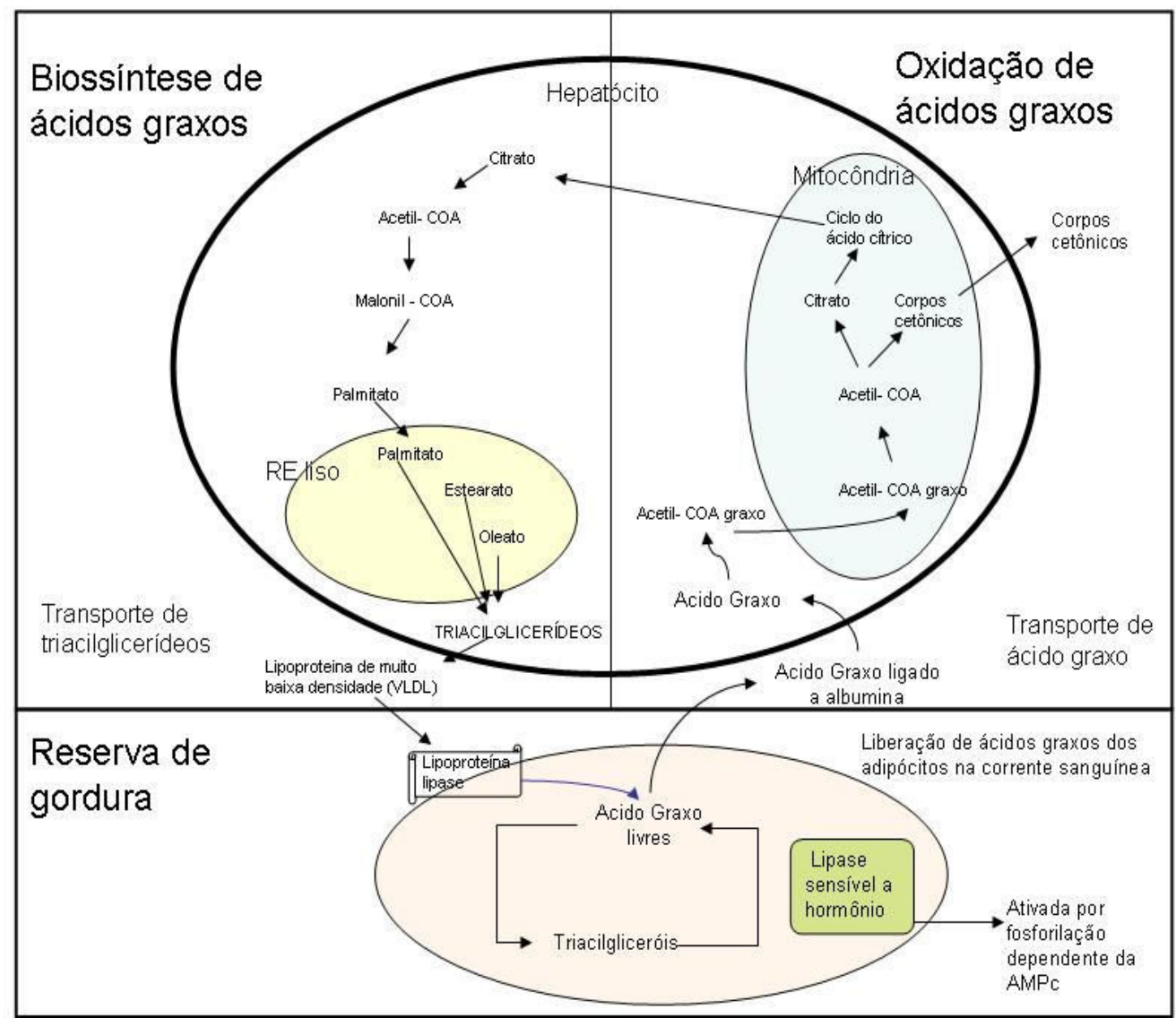

Figura 5- Quadro de biossintese e oxidação dos ácidos

O Citrato sai da mitocôndria e no citoplasma volta a ser Acetil- Coa e produz os ácidos graxos que passam pelo retículo endoplasmático liso e se transformam em triacilgliceróis que são transportados pela lipoproteína de muito baixa densidade (VLDL) e entram no adipócito com o auxilio da lipoproteína lipase.

Os ácidos graxos são componentes vitais das membranas biológicas e influenciam fortemente sua fluidez. Com o aumento dos ácidos graxos 
poliinsaturados, a fluidez da membrana aumenta. Isso porque nos PUFAS as cadeias acil são extremamente flexiveis e podem mudar rapidamente seu estado conformacional. Assim, o número de duplas ligações influencia significativamente a fluidez da membrana. Eles servem também como um importante mediador dos eventos nucleares regulando a expressão de genes específicos envolvidos no metabolismo lipídico e da glicose (LOMBARDO e CHICCO, 2006).

O ácido linoléico conjugado é um componente alimentar funcional bastante estudado nas últimas décadas. Existem mais de vinte diferentes isômeros do ácido linoléico conjugado, que são todos coletivamente chamados de CLAs.

O CLA denomina um conjunto de isômeros posicionais e geométricos do ácido octadecadienóico com duplas ligações conjugadas, que podem ser encontradas nas posições 9 e 11, 10 e 12 ou 11 e 13, entre outras e podem ser em ambas configurações, cis e trans. Estudos demonstraram que a posição da dupla ligação e o seu tipo de isomeria geométrica determinam o papel dele no metabolismo.

Os isômeros mais conhecidos são também o que se apresentam em maior abundância, o CLA trans-10, cis-12 e o CLA cis-9, trans-11. O efeito do CLA na composição corporal e no metabolismo lipídico em cultura de células é induzido pelo trans-10, cis-12, e o crescimento e eficiência alimentar parece estar mais relacionado com o cis-9, trans-11 (PARIZA, et al., 2001).

A partir do estudo pioneiro de $\mathrm{Ha}$ e colaboradores (PARIZA et al., 2001) demonstrando o efeito inibitório do ácido linoléico em neoplasias epidérmicas induzidas pelo benzeno-pireno em camundongos, diversos outros trabalhos têm salientado os efeitos biológicos e fisiológicos do uso de CLA, especialmente os isômeros cis-9; trans-11 (c-9;t-11) e trans-10;cis-12 (t10;c-12), onde, dentre os efeitos fisiológicos observados estão a diminuição da "massa" gordurosa do corpo com aumento da "massa" magra em murinos (PARK et al., 1999; GRANLUND, et al., 2003) e redução do acúmulo lipídico durante a diferenciação de adipócitos humanos e murinos (BROWN et al., 2001; EVANS et al., 2001), sendo que o trans10, cis12 reduz o conteúdo de triglicerídeos em cultura de células de preadipócitos 3T3-L1 em murinos, 
enquanto o cis9, trans11 aumenta, sendo esse triglicerídeo incorporados dentro dos lipídeos neutros e dos fosfolipídeos (EVANS, et al., 2001). Mais especificamente ficou demonstrado que a adição de uma mistura de isômeros de CLA ou a forma $t$-10;c-12 sozinha inibe a expressão do mRNA de genes envolvidos na lipogênese durante a diferenciação dos adipócitos (GRANLUND et al., 2003).

Os ômegas 3 e 6 são lipídeos bioativos produzidos pelas bactérias do rúmen, e estão sendo estudados mais cuidadosamente em cultivos de células in vitro. Um trabalho realizado no Brasil aplicando estes suplementos demonstrou que a modificação do conteúdo de ácidos graxos altera o padrão de expressão gênica de leucócitos humanos (VERLENGIA et al., 2004).

Investigações anteriores mostraram que a adição do ácido linoléico em meios com soro melhora a sobrevivência pós-descongelamento de mórulas (HOCHI et al., 1999).

Vários estudos têm relatado os efeitos positivos do ácido linoléico na criopreservação de embriões bovinos (IMAI et al., 1997; HOCHI et al., 1999; TOMINAGA, 2000; PEREIRA et al., 2008a) e este efeito pode ser resultado de um aumento na conversão de ácidos graxos insaturados na membrana antes do congelamento, e isto pode resultar, num aumento da fluidez da membrana, que pode vir a melhorar a habilidade do embrião ao congelamento (HOCHI et al., 1999; TOMINAGA et al., 2000), porém altas concentrações de ácido linoléico podem ter um efeito prejudicial.

O conteúdo de fosfolipídeos e ácidos graxos não esterificados de oócitos imaturos são menores que os maduros (KIM et al., 2001). Essa diferença pode refletir na perda do fosfolipídeos da membrana do oócito. Essa perda do fosfolipídeos pode aumentar a razão coleterol/fosfolipídeo conduzindo a uma diminuição da fluidez da membrana e uma redução da habilidade a tolerância a baixas temperaturas (ANASH e BUCKLAND, 1994).

Uma proposta de como o CLA melhora a sobrevivência do embrião pósdescongelamento é baseada no que se refere aos efeitos específicos do CLA $t$ 10, c-12 em adipócitos que podem reduzir a síntese e o aumento de ácidos graxos. Este isômero inibe a expressão de vários genes que codificam as 
enzimas da síntese de lipídeos (PETERSON et al., 2003; GRANLUND et al., 2005) assim como a atividade da lipoproteína lípase (PARK et al., 1999).

Segundo José (2005) o CLA trans-10, cis-12 parece ter um efeito inibitório sobre o mecanismo de sintese de lipídeos, mas não sobre a mobilização em culturas de tecido adiposo suíno.

Pereira et al. (2008a) avaliou embriões produzidos na presença de SFB adicionado de CLA trans-10,cis-12, e este tratamento não resultou em diferenças em comparação ao grupo controle, na taxa de clivagem, sexagem, taxa de blastocistos no D7 e D8 e qualidade morfológica. Porém, os embriões suplementados com o CLA tiveram um aumento de pequenas gotas de lipídeos e uma menor quantidade de embriões catalogados como "gordos". Em geral, embriões cultivados com CLA se apresentaram mais "magros" que os controles. A taxa de sobrevivência pós-descongelamento foi maior para os embriões com CLA. Neste trabalho, houve uma redução do conteúdo dos triacilgliceróis induzida pelo CLA t10,c12 durante o cultivo do embrião e isso pode contribuir para um aumento da resistência do embrião à criopreservação, pois segunda a autora, o CLA tem a função de bloquear a entrada de ácidos graxos nos adipócitos, podendo interferir deste modo na deposição de ácidos graxos nos embriões. Em 2007, o mesmo grupo verificou que em meios suplementados com esse CLA houve uma melhora na razão de sobrevivência dos blastocistos depois do congelamento lento e descongelamento (PEREIRA et al.,2007).

Sata et al. (1999) desenvolvendo o trabalho com vacas da raça black Wagiu mediram a composição dos ácidos graxos por cromatografia de gás de oócitos imaturos, embriões de 2 células e blastocistos. Nos oócitos imaturos o mais abundante é o ácido mirístico (59,6\%) seguido do ácido docosahexaenóico (12,3\%). Nos embriões de 2 células produzidos em atmosfera de $5 \% \mathrm{CO}_{2}$ em ar e sem $\mathrm{SFB}$, a composição é semelhante à do oócito imaturo, e os com soro tem altos níveis de ácido palmítico $(27,6 \%)$ e esteárico $(27,2 \%)$ e baixos níveis de mirístico $(21,9 \%)$. Os blastocistos produzidos sem soro têm altos níveis de acido mirístico $(35,7 \%)$, seguido do palmítico $(17,0 \%)$ e esteárico $(12,5 \%)$. E os blastocistos com soro têm altos níveis de palmítico $(30,5 \%)$ esteárico $(24,2 \%)$ e os índices do ácido 
palmitoléico $(16,3 \%)$ e oléico $(12,1 \%)$ aumentaram significativamente. Quando foram medidos os ácidos graxos do soro fetal bovino sozinho, os indices foram de 17,5\% para o oléico, 16,5\% para o palmítico e 12,3\% para o esteárico, perfil similar aos embriões produzidos com soro, sugerindo que há a incorporação dos ácidos graxos presentes no soro nos embriões. Uma observação importante, é que não houve diferenças na quantidade do número de células dos embriões cultivados com e sem soro, e a presença do BSA não interferiu no acúmulo de lipídeos. É valido ressaltar que ocorrem diferenças que podem ser atribuídas por diferentes espécies, raças e individuos usados nos experimentos.

Para Kim et al. (2001), o ácido palmítico é o ácido graxo mais abundante em oócitos imaturos (35\%) e nos maturados (36\%) independente da qualidade, se eram grau I ou II. O ácido oléico é o segundo mais abundante em oócitos grau I, e o esteárico o segundo mais abundante nos grau II. Estes dados estão de acordo com os dados apresentados pela equipe de ZERON et al. (1999). Outro estudo sobre composição dos ácidos graxos foi feita por Van Soom et al. (2001), onde afirmaram que o uso de óleo de silicone ou parafina sobre as gotas de cultivo modifica o conteúdo lipídico dos embriões. Quando os embriões foram vitrificados, a taxa de sobrevivência variou significativamente entre partidas de óleo e de parafina. Eles concluíram que mudanças no conteúdo dos embriões modificam as membranas alterando sua criotolerância. Nos embriões cultivados sem óleo, o ácido graxo mais abundante foi o palmítico $(32,4 \%)$ seguido o oléico $(23,1 \%)$, e para os cultivados com o óleo de silicone como a parafina, o mais abundante foi o linoléico seguido do palmítico.

Em contrapartida, para Pereira et al. (2008a) e Reis et al. (2003), o perfil dos ácidos graxos nos embriões PIV difere do perfil dos ácidos graxos do soro fetal bovino presente no meio de cultivo. Parece assim que os oócitos e embriões em cultura têm mecanismos capazes de selecionar o acúmulo de ácidos graxos, mostrando preferência pelos ácidos graxos "familiares" disponiveis no meio de cultura. Sendo que para estes o ácido graxo mais abundante foi o palmítico, seguido do oléico, esteárico e linoléico. E no soro a seqüência foi o linoléico, esteárico, palmítico e oléico. 
De acordo com Kim et al (2001), em vacas holandesas o ácido palmítico é o ácido graxo mais abundante nos oócitos imaturos de qualidade 1 e 2 , e também nos maturados na presença de soro e sem soro. $\mathrm{O}$ ácido oléico é o segundo mais abundante nos imaturos de qualidade 1 e nos de qualidade 2 o esteárico segue como o segundo.

O ácido linoléico ou os insaturados como o oléico e aracdônico, são mais importantes nos estágios finais de desenvolvimento do embrião, tanto em bovinos como em camundongos. Nos relatos de Haggarty et al. (2006), os embriões humanos que se desenvolvem além do estágio de quatro células têm significativamente maiores concentrações de ácidos graxos poliinsaturados, como o ácido linoléico e o oléico, e menores concentrações de saturados. Os poliinsaturados de cadeia longa, como o ácido aracdônico e o docosahexaenóico (DHA) também tiveram sua concentração aumentada nos estágios mais tardios do desenvolvimento, mas essas diferenças não foram significativas.

A composição dos ácidos graxos dos fosfolipídeos dos oócitos apresenta uma maior porcentagem de ácidos graxos saturados no verão e uma maior porcentagem de mono e poliinsaturados no inverno, e esta diferença de composição é justificada por uma diminuição na temperatura de transição da fase lipídica verificada na membrana de oócitos bovinos (Zeron et al., 2001, 2002).

\subsection{Cultivo in vitro com Soro Fetal Bovino (SFB)}

A suplementação protéica é benéfica ao desenvolvimento embrionário in vitro (CAROLAN et al., 1995), onde o soro fetal bovino (SFB) e a albumina sérica bovina (BSA) são as fontes protéicas mais utilizadas (LONERGAN et al., 1999).

Sabe-se que suplementação com SFB impossibilita examinar as necessidades nutricionais do embrião durante o desenvolvimento (SATA et al., 1999), pois apresenta uma variedade de componentes indefinidos (ácidos 
graxos, fatores de crescimento, aminoácidos, vitaminas). O soro acumula gotas de lipídeos, altera a cinética do desenvolvimento embrionário (PINYOPUMMINTR e BAVISTER, 1994) aumenta a taxa de blastocisto, a taxa de eclosão e o número total de células (ABE e HOSHI, 2003), sendo que para Lonergan et al. (1999) esses são parâmetros indicativos de que o SFB pode melhorar a qualidade dos embriões produzidos. Altas taxas de desenvolvimento de blastocistos são observadas em meios com SFB por muitos autores (PINYOPUMMINTR e BAVISTER, 1991; ECKERT e NIEMANN, 1995; VAN LANGENDOCKT et al., 1997; CHO et al., 2002; PEREIRA et al., 2008a).

Outros pesquisadores acreditam que o SFB é prejudicial para a qualidade do embrião, e procuraram desenvolver sistemas de cultivo livre de SFB e de ácidos graxos onde o SFB é substituído pela albumina bovina (FERGUSON e LEESE, 1999), pelo álcool polivinílico ou suplementados com agentes antioxidantes como a Vitamina E (REIS et al., 2002).

A ausência completa de SFB em sistemas de cultivo diminui a competência dos embriões in vitro (CAROLAN et al., 1995; MASSIP et al., 1996; VAN LANGENDONKT et al., 1996). Meios completamente definidos, livres de proteínas (suplementado com álcool polivinílico, PVA) resultam em baixas taxas de desenvolvimento, se comparados com aqueles suplementados com SFB ou BSA, e apresentam resultados críticos quanto à viabilidade, número de células e taxa de prenhez (KESKINTEPE e BRACKETT, 1996; LIM et al., 2007).

A equipe de Guerin et al. (2001) afirmou que meios quimicamente definidos são menos capazes de proteger o embrião contra o estresse oxidativo. Quando o embrião é produzido na presença de co-cultura a quantidade de embriões aumenta e eles são mais capazes de suportar o processo de criopreservação.

Entretanto, a síntese ou o acúmulo excessivo de lipídios no citoplasma dos embriões induzido pela presença de SFB no meio de cultura é um problema patente do desenvolvimento embrionário dando aos embriões uma aparência escura quando comparados com outros embriões produzidos sem SFB (ABE et al., 1999, 2002; ABE e HOSHI, 2003; FARIN et al., 2001; 
FERGUSON e LEESE, 1999; REIS et al., 2003; RIZOS et al., 2003, 2008; SHAMSUDDIN e RODRIGUEZ-MARTINEZ, 1994; THOMPSON et al., 1995, 1997).

O acúmulo de lipídeos citoplasmáticos nos embriões desenvolvidos em meios com SFB pode ser resultado da incorporação das lipoproteínas que podem ser prejudiciais à função das mitocôndrias. O mecanismo pelo qual ocorre o acúmulo de lipídeos nos embriões ainda é desconhecido. Existe uma correlação entre função da mitocôndria, consumo de oxigênio e qualidade do embrião. As mitocôndrias nos embriões cultivados sem SFB são alongadas e numerosas, e nos com SFB, são esféricas ou ovóides, indicando uma imaturidade. A maturação da mitocôndria em embriões é associada com um aumento no reflexo do metabolismo, consumo oxigênio e produção de gás carbônico. Blastocistos e mórulas produzidos em meios com SFB possuem grandes gotas de lipídeos e eletro densas, enquanto os sem soro tem poucas e pequenas (ABE e HOSHI, 2003; ABE et al., 1999, 2002).

Culturas de embriões bovinos produzidos in vitro sem SFB reduzem o acúmulo de gotas de lipídeos citoplasmáticos em blastocistos assim como a remoção mecânica do excesso intracelular de lipídeos nos blastocistos iniciais significativamente melhoraram a resistência a criopreservação ( $\mathrm{ABE}$ et al.,1999, 2002; DIEZ et al., 2001).

Três mecanismos têm sido sugeridos pelo qual o SFB pode interferir no metabolismo lipídico dos embriões: o soro pode aumentar a neosíntese de lipídeos (especialmente os triacilglicerídeos) em embriões (ABD EL RAZEK et al., 2000); lipoproteínas presentes no soro podem ser internalizadas pelas células aumentando seu conteúdo lipídico intracelular (FERGUSON e LEESE, 1999; SATA et al., 1999); e, a presença de soro pode alterar o metabolismo lipídico na mitocôndria, principalmente aumentando os estoques de lipídeos intracelulares (ABE e HOSHI, 2003).

Todavia, a remoção completa do SFB dos meios de cultivo não é uma alternativa viável, quando se considera a produção em grande escala de embriões bovinos destinados à criopreservação, devido, principalmente, ao tempo necessário para retirar totalmente todas as células do cumulus, 
separadamente para o conjunto de complexos cumulus-oócito de cada doadora e seus acasalamentos.

\subsection{Atmosfera gasosa de $5 \% \mathrm{O}_{2} \times 20 \% \mathrm{O}_{2}$}

A atmosfera mais utilizada no co-cultivo de embriões mundialmente é a de $5 \% \mathrm{CO}_{2}$ em ar, e a concentração de oxigênio é maior que a normalmente encontrada no oviduto de mamíferos, que varia entre 5 a $8 \%$ (BAVISTER, 1995; FUJITANI et al., 1997).

A atmosfera gasosa é uma importante variável na produção in vitro de embriões, uma vez que o estresse oxidativo provocado por altas concentrações de $\mathrm{O}_{2}$ pode influenciar a qualidade dos embriões. Essa alta concentração de $\mathrm{O}_{2}$ na mistura gasosa exerce efeito deletério sobre o desenvolvimento embrionário bovino in vitro, principalmente quando cultivados sem o co-cultivo de células somáticas (FUKUI et al., 1999), provavelmente pelo aumento de radicais de oxigênio livres no meio (BAVISTER, 1995; FUJITANI et al., 1997). O aumento de radicais livres de oxigênio pode estar relacionado com uma disfunção mitocondrial devido ao estresse (LIU et al., 2003), podendo alterar a atividade celular (ADLER et al., 1999) e causar danos ao DNA (VAN SOON et al., 2002).

Takahashi et al. (2000) mostraram que o estresse oxidativo, ocasionado pela elevada concentração de oxigênio atmosférico, pode estar relacionado a um retardo no desenvolvimento de embriões e que concentrações de oxigênio acima de $20 \%$ provocam um aumento da freqüência de fragmentação no DNA devido à formação de $\mathrm{H}_{2} \mathrm{O}_{2}$ intracelular, contribuindo para a redução do potencial de desenvolvimento do embrião.

Reduzir a concentração de $\mathrm{O}_{2}$ para aproximadamente $5 \%$ pode reduzir a presença de radicais livres de oxigênio (VARISANGA et al., 2002) e diminuir os efeitos danosos no DNA durante o desenvolvimento (TAKAHASHI et al., 1999), produzindo melhores taxas de blastocistos com maiores quantidades

de células (DUMOULIN et al., 1999) e embriões mais semelhantes ao in vivo quanto à expressão de genes (WRENZYCKI et al., 2001). 
No trabalho desenvolvido por Rizos et al. (2003), a presença das células do cumulus nos embriões produzidos em meio SOF supera os efeitos deletérios da alta concentração de oxigênio, resultando na produção de embriões de qualidade semelhantes para as atmosferas de 5 e $20 \%$ de oxigênio.

Tem sido postulado que a co-cultura pode ter ação benéfica de maneira facilitadora através da produção de fatores embriotróficos ou proteção através da redução ou remoção de substâncias potencialmente nocivas ou modificando a concentração dos constituintes do meio em níveis mais apropriados para o desenvolvimento do embrião (BAVISTER, 1995). Confirmando esses resultados, para a equipe de Guerin et al. (2001), a quantidade de embriões que é produzida na presença de co-cultura é aumentada e eles são mais capazes de suportar o processo de criopreservação.

\subsection{Viabilidade embrionária (taxa prenhez)}

É claro que o melhor critério para avaliar a viabilidade do embrião é sua habilidade para gerar bezerros sadios e normais após o nascimento. Entretanto, a viabilidade dos embriões pós-descongelamento pode ser verificada por diferentes métodos, o mais comum é a avaliação in vitro da taxa de re-expansão às 24 e 48 horas, a avaliação da taxa de eclosão às 72 e 96 horas de CIV (WHITTINGTAM, 1978; MARTINEZ et al., 1998; SOMMERFELD e NIEMANN, 1999; KAIDI et al., 2000) e também a avaliação do número de células totais, da massa celular interna e do trofectoderma (IWASAKI et al., 1992; KAIDI et al., 1996). A sobrevivência pósdescongelação é influenciada pela idade, estágio de desenvolvimento, qualidade do embrião e o tipo de sistema em qual foi produzido (LEIBO e LOSKUTOFF, 1993).

A competência dos embriões in vitro é medida por: características morfológicas, taxa de desenvolvimento, cinética de clivagem, capacidade de gerar prenhezes ou nascimentos saudáveis, e mais um indicativo da 
qualidade seria a sobrevivência à criotolerância (LEIBFRIEDRUTLEDGE, 1999).

Segundo Hasler (1998) os fatores que influenciam a manutenção de uma prenhez são: o sistema de cultivo, a qualidade do embrião, o avaliador do embrião, o número de embriões transferidos para as receptoras, a sincronização do dia do ciclo estral com o estágio de desenvolvimento do embrião, o técnico da transferência, se o embrião é fresco ou congelado, e os efeitos causados pelo estresse calórico no embrião ou na receptora.

A criopreservação de embriões produzidos in vitro (PIV) é de fundamental importância para a difusão do material genético superior em larga escala, pois, além de favorecer o armazenamento dos embriões por períodos extensos e com reduzida perda da capacidade de desenvolvimento (KAIDI, et al., 1999), propicia maior flexibilidade quanto à conservação e a difusão do material genético (KHURANA e NIEMANN, 2000c), o que auxilia o desenvolvimento do comercio mundial desses animais.

Contudo, sob condições comerciais a taxas de prenhezes dos embriões produzidos in vitro congelados/descongelados são muito reduzidas (HASLER et al., 1995).

Dados da Sociedade Brasileira de Transferência de Embriões (2007), no Brasil foram produzidos no ano de 2006, 204.333 embriões FIV e destes 196.663 foram transferidos à fresco e somente 7.578 foram congelados $(3,7 \%)$ do total. 


\section{Produção de embriões in vitro com adição dos diferentes ácidos graxos em atmosfera de $20 \% \mathrm{CO} 2 \mathrm{em}$ ar}

\subsection{HIPÓTESE}

O acúmulo excessivo de lipídeos nos embriões produzido in vitro diminui a viabilidade do embrião após a criopreservação, principalmente em sistemas de cultivo suplementados com SFB. Baseado nestas informações, este estudo teve como hipótese que: a adição de ácidos graxos ao meio de cultivo suplementado com SFB reduz o conteúdo lipídico nos embriões bovinos produzidos in vitro favorecendo a sua criotolerância.

\subsection{OBJETIVOS}

1. Averiguar o efeito da adição de diferentes ácidos graxos ao meio de cultivo na taxa de produção in vitro de embriões bovinos (taxa de clivagem e de blastocisto).

2. Analisar a qualidade dos embriões produzidos por meio da contagem de núcleos (corante Hoechst) assim como seu conteúdo lipídico total (corante Nile Red).

3. Verificar a sobrevivência in vitro, através da taxa de re-expansão e de eclosão dos embriões congelados/descongelados produzidos nos diferentes tratamentos.

4. Verificar a viabilidade in vivo, pela taxa de prenhez dos embriões criopreservados produzidos em dois tratamentos após transferência para receptoras sincronizadas. 


\subsection{JUSTIFICATIVA}

O aumento da eficiência na produção de embriões bovinos com alta taxa de sobrevivência pós-criopreservação tem importância estratégica na disseminação e aprimoramento das metodologias de melhoramento genético dos rebanhos. A transferência de embriões congelados elimina a necessidade de sincronizar um grande número de receptoras além de permitir o transporte e a exportação destes embriões para programas de melhoramento genético em outros estados e países.

Existe evidência concreta de que o cultivo de embriões na presença de ácidos graxos conjugados melhora a viabilidade do embrião pósdescongelamento e que, possivelmente, esta modificação se dá por conta da atividade deste ácido graxo no metabolismo lipídico embrionário. Este estudo visou avaliar o efeito destes ácidos graxos, bem como de outros ácidos graxos essenciais sobre o desenvolvimento embrionário bovino in vitro e sua criotolerância.

\subsection{MATERIAL E MÉTODOS}

\subsubsection{Local do Experimento}

A produção in vitro dos embriões e a criopreservação foram desenvolvidas tanto no Laboratório da Vitrogen como no laboratório de Morfofisiologia Molecular e Desenvolvimento do Departamento de Ciências Básicas; Faculdade de Zootecnia e Engenharia de Alimentos da Universidade de São Paulo - Campus de Pirassununga. As análises de contagem de núcleos, assim como a de conteúdo lipídico foram realizadas no Laboratório de Morfofisiologia Molecular e Desenvolvimento. As transferências de embriões foram realizadas em centrais de receptoras da região de Uberaba e Uberlândia (TRANSGEN). 


\subsubsection{Produção in vitro de embriões}

A produção in vitro de embriões consiste na colheita de oócitos viáveis para maturação in vitro, fecundação com espermatozóides capacitados in vitro e o desenvolvimento do zigoto até o estádio de blastocisto em sistema de co-cultivo. Para isso, os oócitos foram obtidos de ovários de vacas zebuínas ou azebuadas colhidos em de abatedouros localizados na região. Somente oócitos com cumulus compacto completo e citoplasma límpido e de aspecto homogêneo (finas granulações) foram utilizados nos experimentos. Os oócitos foram maturados em TCM199 com sais de Earles, glutamina e $\mathrm{NaHCO}_{3}$ suplementado com $10 \%$ de SFB, piruvato $(22 \mu \mathrm{g} / \mathrm{ml})$, gentamicina (50 $\mu \mathrm{g} / \mathrm{ml}), 0,5 \mu \mathrm{g}$ de FSH/ml, $50 \mu \mathrm{g}$ de LH/ml e $1 \mu \mathrm{g}$ de estradiol/ml. Os complexos cumulus-oócito (CCO) foram maturados em microgotas de $100 \mu 1$ de meio de maturação, cobertas com óleo mineral e levados a incubadora a $38,5^{\circ} \mathrm{C}, 5 \% \mathrm{CO}_{2}$ em ar e com máxima umidade, durante 22-24 horas.

Após o período de maturação, os oócitos foram submetidos à fecundação in vitro, em microgotas de $100 \mu 1$ de meio TALP suplementado com heparina $(10 \mu \mathrm{g} / \mathrm{ml})$, piruvato $(22 \mu \mathrm{g} / \mathrm{ml})$, gentamicina $(50 \mu \mathrm{g} / \mathrm{ml})$, BSA sem ácidos graxos $(6 \mathrm{mg} / \mathrm{mL})$ e solução de PHE $(2 \mu \mathrm{M}$ de penicilamina, $1 \mu \mathrm{M}$ de hipotaurina e $0,25 \mu \mathrm{M}$ de epinefrina). As palhetas de sêmen de um touro Nelore foram descongeladas em banho-maria a $35^{\circ} \mathrm{C}$, durante 30 segundos e seu conteúdo foi centrifugado em gradiente de Percoll (45 e 90\%) para obtenção dos espermatozóides móveis, além da remoção do diluidor e do plasma seminal. A concentração espermática foi de $1 \times 10^{6}$ células/ml e os oócitos foram transferidos para as microgotas (20 oócitos/gota) junto com os espermatozóides onde permaneceram sob incubação em atmosfera com 5\% de $\mathrm{CO}_{2}$ em ar a $38,5^{\circ} \mathrm{C}$ durante 22 horas.

Após o processo de MIV e FIV, os zigotos tiveram as células do cumulus parcialmente removidas e foram cultivados in vitro em meio CR2 modificado suplementado com $5 \%$ SFB e $3 \mathrm{mg} / \mathrm{ml}$ de BSA livre de ácidos graxos (WATANABE et al., 1999) ou, cultivados em presença de um dos 
quatro ácidos graxos (LA - ácido linoléico, CLA - ácido linoléico conjugado, EPA - ácido eicosapentaenóico e DHA - ácido docosahexaenóico) adicionados ao meio de cultivo em placas de quatro poços sem óleo mineral. Decorridas 48 hpi (horas pós-inseminação) foi avaliada a taxa de clivagem, renovando o meio de cultivo (feeding) de todos os grupos. No dia 6,7 e 8 de cultivo foi avaliado o desenvolvimento embrionário. No dia 7 , os embriões foram criopreservados e transferidos, e no dia 8, foi analisada a concentração lipídica mediante avaliação da intensidade de fluorescência pela técnica Nile Red e a contagem do número de células pela coloração com Hoechst.

\subsubsection{Análise qualitativa dos embriões - coloração Hoechst}

Os embriões de cada grupo que atingiram o estádio de blastocisto oito dias após a FIV foram avaliados quanto ao número de células totais coradas com Hoechst 33342, para medir a competência do desenvolvimento embrionário. Para tanto, foram fixados em paraformoldeído 3,7\% acrescido de 10\% de TRITON 100X durante uma hora e, em seguida, transferidos a uma solução de PBS com 0,3\% de BSA acrescido de 1\% de TRITON 100X por mais uma hora em temperatura ambiente. A coloração se deu com a introdução dos embriões em glicerol contendo o corante vital Hoechst e a contagem dos núcleos vivos foi realizada sob microscopia de epifluorescência com excitação de $365 \mathrm{~nm}$ e emissão de 420nm sob objetiva de 40X.

\subsubsection{Análise do conteúdo total de lipideos nos embriões - coloração Nile Red}

A quantificação do conteúdo lipídico foi avaliada com a utilização da técnica de Nile Red segundo Genicot et al. (2005). Esta técnica é altamente sensível e a quantidade total de lipídeos é correlacionada com a emissão de fluorescência.

No dia 8 do estádio embrionário, os blastocistos foram classificados e posteriormente separados em grupos de acordo com o grau de desenvolvimento. Os embriões permaneceram por uma hora em $1 \mathrm{ml}$ de 
paraformoldeído 3,7\% acrescido de 10\% de TRITON 100X. Em seguida, mais uma hora em $1 \mathrm{ml}$ de PBS com 0,1\% PVP. A coloração com Nile Red, para avaliação da incidência de lipídeos intracelulares foi realizada com a adição de $10 \mu \mathrm{g} / \mathrm{ml}$ do corante para cada $\mathrm{ml}$ de solução salina 0,9\%, onde permaneceram protegidos da luz e a temperatura ambiente durante o período de 3 horas. Terminado esse passo, os embriões foram lavados em 3 banhos de solução salina 0,9\% com 0,1\% PVP, e com uma pipeta Pasteur transferidos para lâminas com $10 \mu$ l de glicerol.

Os embriões foram fotografados em microscópio de epifluorescência, com exposição de 200 ms, excitação de 450-490 nm e emissão 515 nm em objetiva de 40X. A intensidade de fluorescência foi avaliada com o "Software Image J" (NIH - EUA).

\subsubsection{Criopreservação dos embriões}

Grupos de embriões obtidos no dia $7^{\circ}$ dia de cultivo in vitro foram congelados em palhetas plásticas de 0,25 ml (IMV International) contendo a solução crioprotetora de $1.5 \mathrm{M}$ de etileno glicol, $0,1 \mathrm{M}$ de sacarose e 0,4 $\mathrm{mg} / \mathrm{ml}$ de (BSA) albumina sérica (solução de Ethylene Glycol Freeze Plus AB Technology $\left.{ }^{\circledR}\right)$.

Depois de classificados, os embriões foram lavados em 3 gotas de Holding Plus AB Technology ${ }^{\circledR}$ (Hepes e BSA) e em seguida, permaneceram 9 minutos na solução crioprotetora e envasados um a um, sendo a primeira e a terceira coluna preenchida com holding, e a segunda coluna a solução criopretotora com o embrião.

As palhetas foram levadas à máquina de congelamento de embriões (FREEZE CONTROL - CL 5000) que estava estabilizada a $-6^{\circ} \mathrm{C}$, e decorridos dois minutos foi realizado o seeding. A máquina permaneceu por dez minutos a $-6^{\circ} \mathrm{C}$, e a taxa de resfriamento foi de $0,5^{\circ} \mathrm{C} /$ minuto até chegar à temperatura de $-32^{\circ} \mathrm{C}$. Terminada a curva, os embriões permaneceram estabilizados por 5 minutos antes de serem mergulhados em Nitrogênio líquido e armazenados. 
Os embriões foram descongelados e transferidos pela técnica de transferência direta (One step). Depois de retiradas do nitrogênio, as palhetas permaneceram no ar por 10 segundos e foram para o banho Maria a $35^{\circ} \mathrm{C}$ por 20 segundos, seguindo para o estudo de re-expansão (sobrevivência in vitro) ou a inovulação nas receptoras (sobrevivência in vivo).

\subsubsection{Re-expansão dos embriões pós-descongelação: Sobrevivência in vitro}

$\mathrm{Na}$ taxa de re-expansão, o protocolo de descongelamento foi o mesmo do descrito acima. Os embriões permaneceram por no máximo 4 minutos na solução crioprotetora com holding, e lavados quatro vezes em meio de cultivo, com ou sem AG. Após esse período, os embriões foram submetidos ao cultivo in vitro conforme descrito no item 3.4.2. Foram avaliadas as taxas de sobrevivência in vitro (re-expansão às 24 horas e 48 horas pósdescongelamento), assim como a taxa de eclosão.

\subsubsection{Transferência dos embriōes para receptoras: sobrevivência in vivo}

Dois grupos de AG (CLA e EPA) mais o grupo controle foram submetidos ao teste de viabilidade in vivo. Para tanto, os embriões foram transferidos de maneira não cirúrgica para receptoras sincronizadas.

De acordo com a classificação da Sociedade Internacional de Transferência de Embriões (IETS) os embriões de grau I foram transferidos para fêmeas aptas a inovulação.

Para proporcionar uma visão eqüitativa entre os grupos, as receptoras foram divididas em função do escore de condições corporais, classificadas de 1 a 9, segundo RICHARD et al. (1986) e, em função da atividade ovariana, com fêmeas ciclando com ovários acima de $30 \mathrm{~mm}$, macios com presença de corpo lúteo ou útero com turgidez acentuada. 
O experimento seguiu em delineamento inteiramente casualizado, com seis grupos distintos:

* G1: Transferência a fresco dos embriões cultivados in vitro na ausência de AG (Controle);

* G2: Transferência a fresco dos embriões cultivados in vitro na presença de AG (CLA);

* G3: Transferência a fresco dos embriões cultivados in vitro na presença de AG (EPA);

* G4: Transferência de embriões congelados cultivados in vitro na ausência de AG (Controle Crio);

* G5: Transferência de embriões congelados cultivados in vitro na presença de AG (CLA Crio);

* G6: Transferência de embriões congelados cultivados in vitro presença de AG (EPA Crio).

\subsubsection{Diagnóstico de gestação}

Após 35 dias da realização da transferência dos embriões, foi feito o diagnóstico de gestação via retal, mediante exame ultra-sonográfico, com utilização de aparelho Aloka SSD 500 e um transdutor linear (5 MHz) para verificação da presença do concepto e batimento cardíaco.

Aos 90 dias de gestação foi realizada novamente a ultra-sonografia para avaliação das perdas embrionárias ocorridas entre os períodos, monitoramento do batimento cardíaco. Neste estudo não foram observadas perdas embrionárias e os resultados obtidos aos 35 dias se repetiu aos 90 dias.

\subsection{ANÁLISE ESTATÍSTICA}

Resultados de características como a taxa de clivagem, taxa de blastocistos e porcentagem de eclosão foram avaliados por ANOVA e as médias comparadas pelos testes de Tukey, conforme procedimento do 
programa JMP versão 5.1 (SAS Inc., 2004). Resultados de avaliação de características de qualidade como número de núcleos e concentração de lipídeos também foram avaliadas pelo mesmo método.

A taxa de re-expansão às 24 e 48 horas, eclosão D10, taxa de gestação, além da comparação de cada um dos tratamentos à fresco e congelados dois a dois, foi utilizado o método Qui quadrado $\left(\mathrm{X}^{2}\right)$, conforme procedimento do programa JMP versão 5.1 (SAS Institute Inc., 2004). 
3.6. DELINEAMENTO EXPERIMENTAL

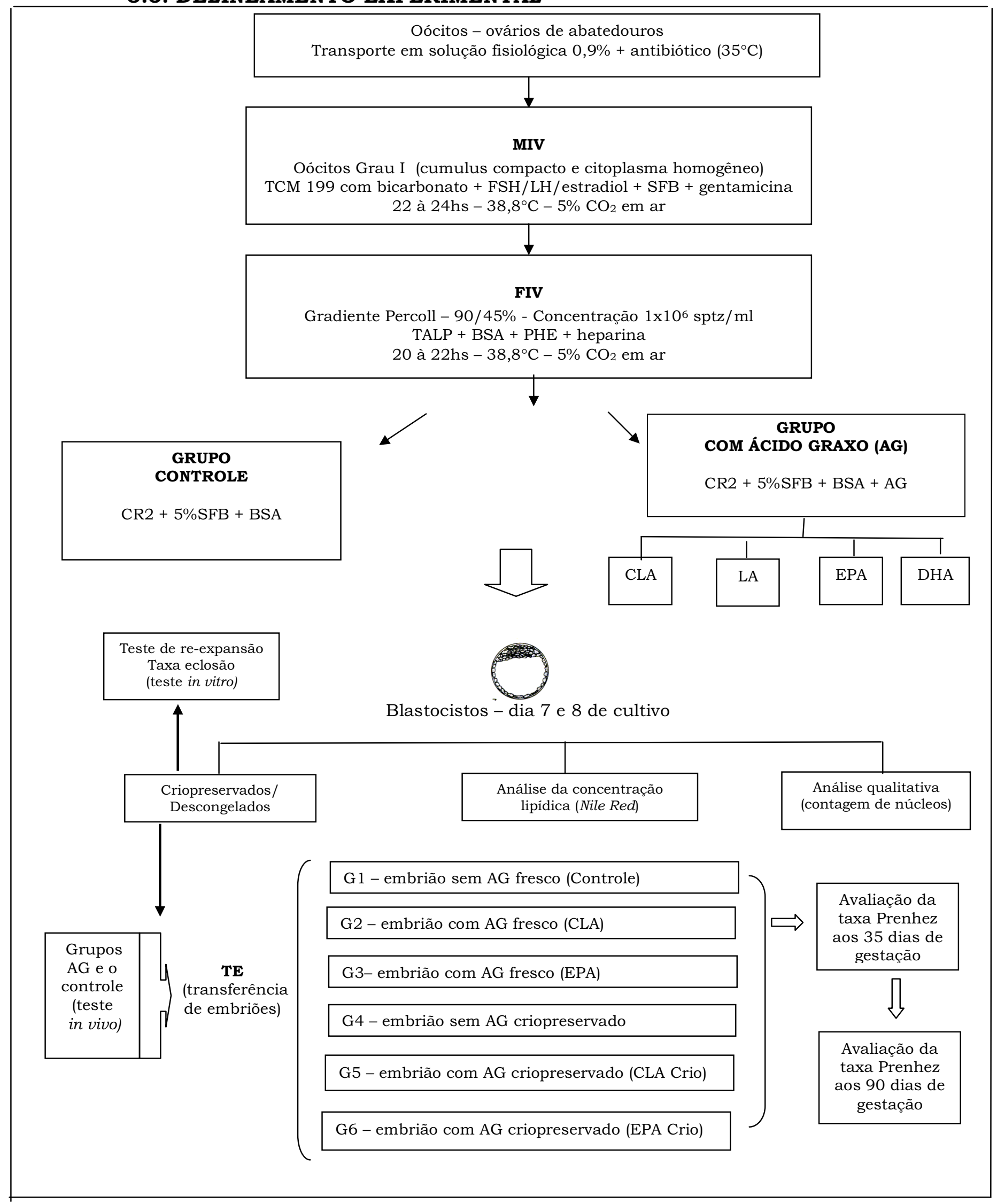




\subsection{RESULTADOS}

Visando atingir o objetivo do experimento, que foi verificar se a adição de ácidos graxos (AG) no sistema de cultivo in vitro de embriões interfere na produção, foram realizados vários experimentos: Avaliação da taxa de clivagem e de blastocistos e da qualidade dos mesmos mediante a contagem de núcleos dos blastocistos produzidos no oitavo dia de cultivo, assim como o conteúdo lipídico observados em blastocistos individuais. Em seguida serão apresentados também os resultados de sobrevivência in vitro póscongelamento/descongelamento com a taxa de re-expansão e eclosão dos embriões submetidos novamente ao cultivo e a taxa de gestação de dois grupos tratados com os AG selecionados para efetuar a transferência de embriões criopreservados e frescos (grupo controle, grupo CLA e EPA).

\section{Desenvolvimento embrionário - Taxa de clivagem, blastocisto e eclosão}

O meio utilizado para o cultivo de embriões, o CR2 modificado, foi suplementado com os ácidos graxos (CLA, LA, EPA e DHA) e foi avaliada a influência da adição destes na produção in vitro de embriões (taxa de clivagem, taxa de blastocistos nos dias 7 e 8 de cultivo, e eclosão no dia 10).

Como evidenciado na Tabela 1 , houve diferença significativa entre os grupos quanto à taxa de clivagem, onde a taxa do controle não diferiu dos tratamentos com ' $\Omega 6$ (CLA e LA), no entanto foi maior do que os grupos com ' 3 (EPA e DHA). Nos blastocistos (média de 32,49\%), houve uma diferença para o grupo EPA $(27,76 \%)$ que teve taxa inferior aos grupos suplementados com LA, CLA e CONTROLE e não diferiu do DHA (mesmo grupo ômega 3). A taxa de eclosão não diferiu entre os grupos, onde a média permaneceu em $50,25 \%$. Como podemos observar, a adição de AG no sistema de cultivo não interferiu na produção de embriões para os grupos tratados com ômega 6, e no entanto teve efeito negativo nos grupos tratados com ômega 3 . O aspecto morfológico visualizado em estereomicroscópio aparentemente foi semelhante entre os grupos (Figura 6). 
Tabela 1. Taxas de clivagem, de blastocistos e eclosão a partir de zigotos cultivados em diferentes suplementações no meio de cultivo CR2 + SFB + BSA em atmosfera de $5 \%$ de $\mathrm{CO}_{2}$ em ar (CONTROLE, CLA, LA, EPA e DHA).

\begin{tabular}{|c|c|c|c|c|c|}
\hline Grupos & Repetições & $\begin{array}{c}\text { N. de } \\
\text { Oócitos }\end{array}$ & $\%$ Clivagem ${ }^{a}$ & $\%$ Blastocisto a & \% Eclosão a \\
\hline CONTROLE & 68 & 2.347 & $73,16 \pm 1,32 \% \mathrm{a}$ & $32,00 \pm 1,64 \% \mathrm{a}$ & $51,52 \%$ a \\
\hline CLA & 65 & 2.574 & $69,54 \pm 1,37 \%$ ab & $34,77 \pm 1,70 \% \mathrm{a}$ & $50,40 \%{ }^{\mathrm{a}}$ \\
\hline LA & 54 & 2.221 & $68,48 \pm 1,56 \%$ ab & $36,29 \pm 1,93 \%{ }^{\mathrm{a}}$ & $51,44 \%{ }^{\mathrm{a}}$ \\
\hline EPA & 61 & 2.435 & $68,38 \pm 1,42 \% \mathrm{~b}$ & $27,76 \pm 1,76 \%^{\mathrm{b}}$ & $49,25 \% \mathrm{o}^{\mathrm{a}}$ \\
\hline DHA & 18 & 746 & $66,22 \pm 2,54 \%$ b & $30,29 \pm 3,16 \%$ ab & $40,00 \%{ }^{a}$ \\
\hline TOTAL & 205 & 10.323 & $69,62 \%$ & $32,49 \%$ & $50,25 \%$ \\
\hline
\end{tabular}

a: Dados dentro da mesma coluna não apresentam diferença significativa $(P>0,05)$

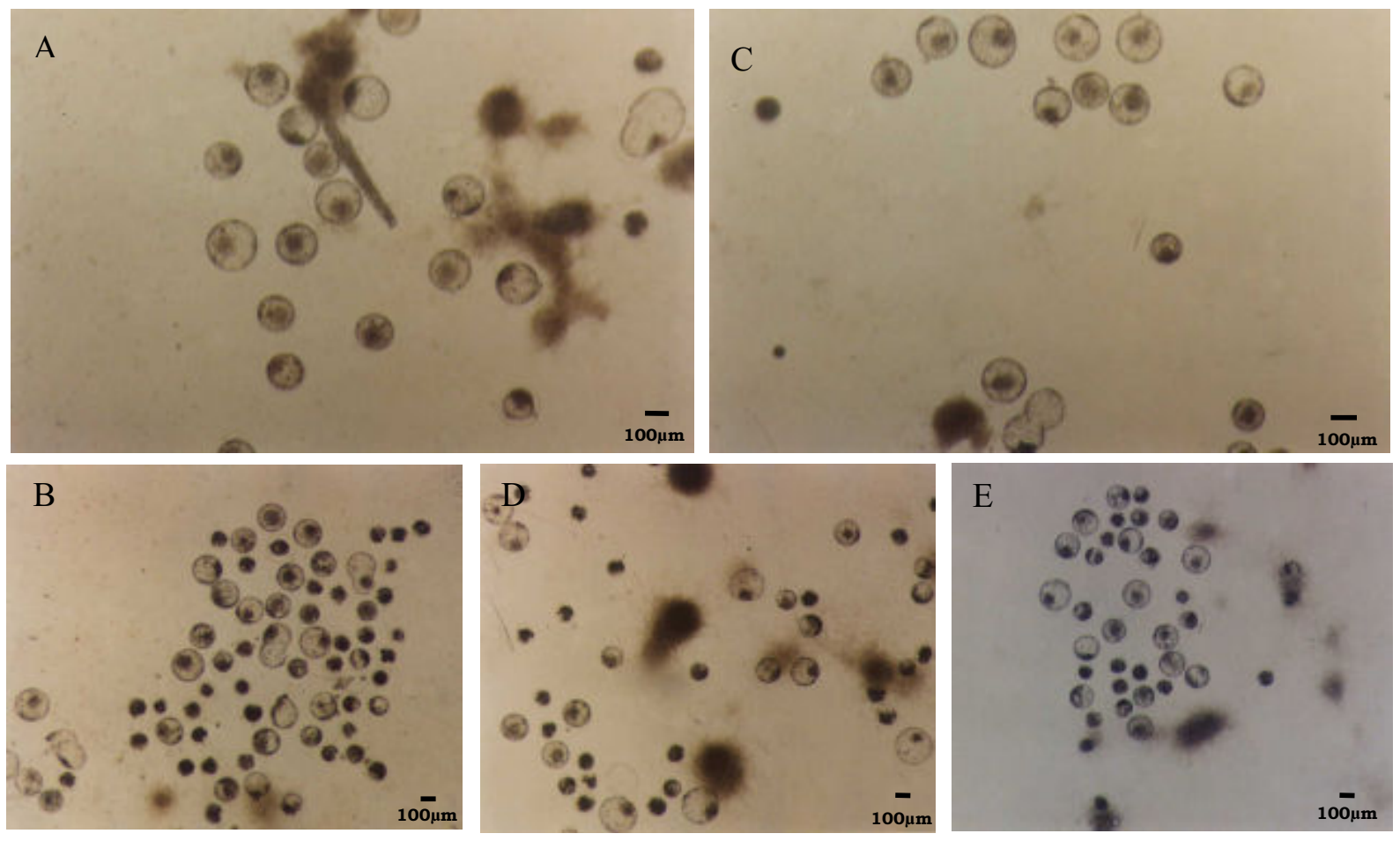

Figura 6. Fotomicrografia de embriões produzidos nas diferentes suplementações de AG no meio de cultivo, no dia 8 de cultivo, A - Grupo controle; B - Grupo CLA; C Grupo LA; D - Grupo EPA; E - Grupo DHA. 


\section{Qualidade embrionária - Contagem de núcleos}

Com relação à qualidade dos embriões produzidos nos diferentes meios de cultivo foi observada diferença entre os grupos na contagem de núcleos de blastocistos no $8^{\circ}$ dia de cultivo, sendo que o grupo LA foi melhor que o EPA e os demais grupos não diferiram entre si. O número total de células dos grupos está representado na Tabela 2 e as imagens na Figura 7.

Tabela 2. Contagem de núcleos de blastocistos produzidos no dia 8 de cultivo no grupo controle e nas diferentes suplementações de AG (CLA, LA, EPA e DHA).

\begin{tabular}{ccc}
\hline Grupo & N. de Embriões & N. Núcleos ${ }^{\mathrm{a}}$ \\
\hline CONT & 106 & $134,74 \pm 4,84^{\mathrm{ab}}$ \\
CLA & 168 & $143,14 \pm 4,11^{\mathrm{ab}}$ \\
LA & 160 & $147,74 \pm 4,18^{\mathrm{a}}$ \\
EPA & 106 & $131,23 \pm 4,84^{\mathrm{b}}$ \\
DHA & 65 & $133,32 \pm 5,88^{\mathrm{ab}}$ \\
\hline TOTAL & 605 & 139,74 \\
\hline 0,05) & a: Dados dentro da mesma coluna não apresentam diferença significativa $(\mathrm{P}>$
\end{tabular}




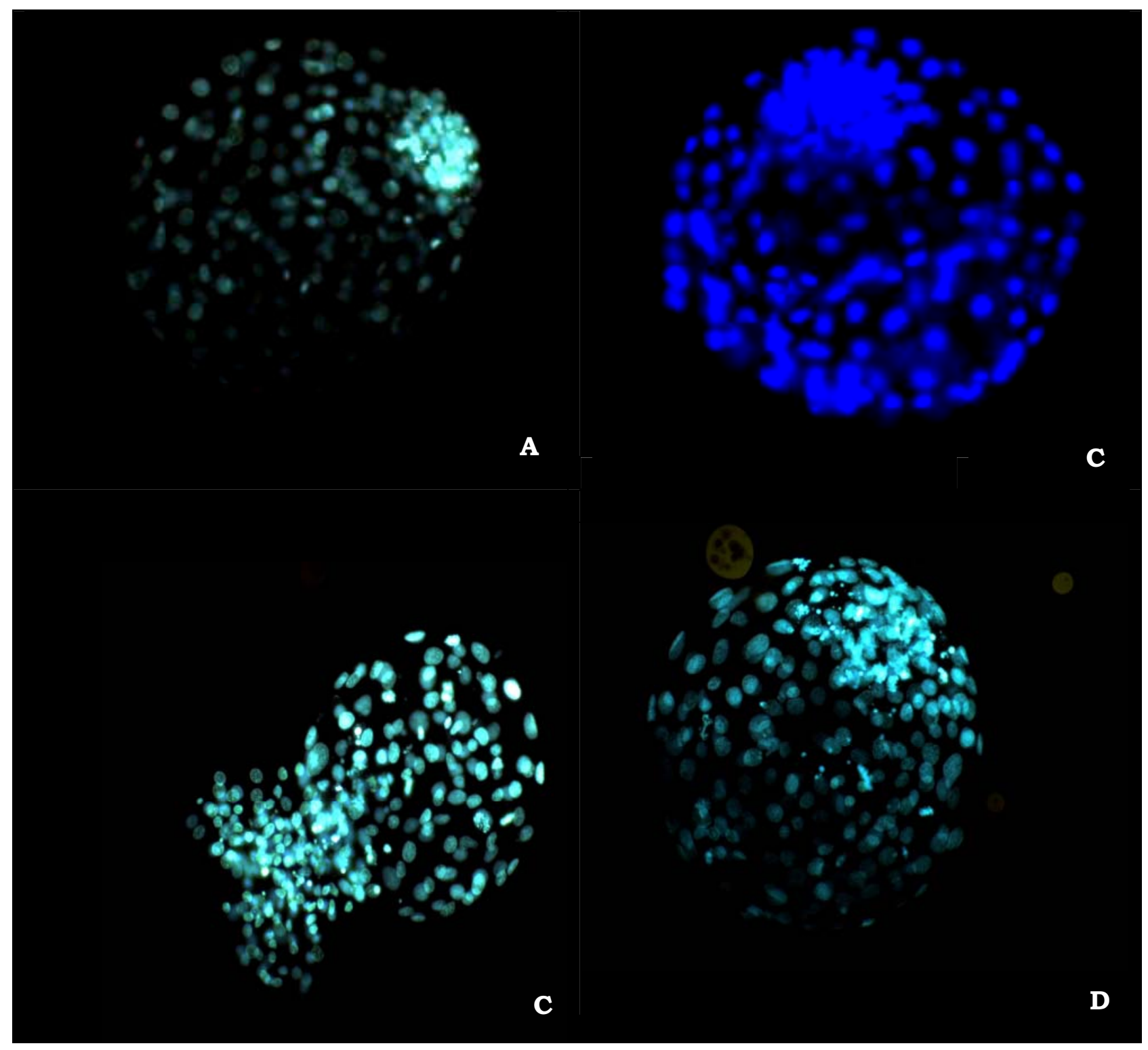

Figura 7. Fotomicrografia em epifluorescência de embriões corados com H33342, no estádio de blastocisto expandido no dia 8 de cultivo. A - Grupo LA; B - Grupo CLA; C Grupo Controle; D - Grupo EPA.

\section{Qualidade embrionária - conteúdo lipídico nos blastocistos}

Além dos estudos de potencial de desenvolvimento embrionário e contagem de núcleos dos blastocistos, parte dos embriões (281 embriões) foi submetida à técnica de coloração com Nile Red, onde se determinou a quantidade total de lipídeos nos embriões individualmente. 
Como podemos observar na Tabela 3 não houve diferença entre os grupos $(\mathrm{P}>0,05)$ nos blastocistos expandidos no oitavo dia de cultivo. $\mathrm{Na}$ Figura 8 podemos visualizar a coloração dos embriões com o corante Nile Red.

Tabela 3. Densidade Integrada Normalizada (conteúdo total lipídico) em blastocistos expandidos oriundos no grupo controle e nos diferentes grupos tratados com AG (CLA, LA, EPA e DHA).

\begin{tabular}{ccc}
\hline Grupo & N. de Embriões & $\begin{array}{c}\text { Densidade Integrada } \\
\text { Normalizada }\end{array}$ \\
\hline CONTROLE & 67 & $0,9794 \pm 0,043^{\mathrm{a}}$ \\
CLA & 91 & $0,9627 \pm 0,038^{\mathrm{a}}$ \\
LA & 56 & $1,014 \pm 0,0483^{\mathrm{a}}$ \\
EPA & 62 & $0,9691 \pm 0,0487^{\mathrm{a}}$ \\
DHA & 5 & $0,8883 \pm 0,1702^{\mathrm{a}}$ \\
\hline
\end{tabular}

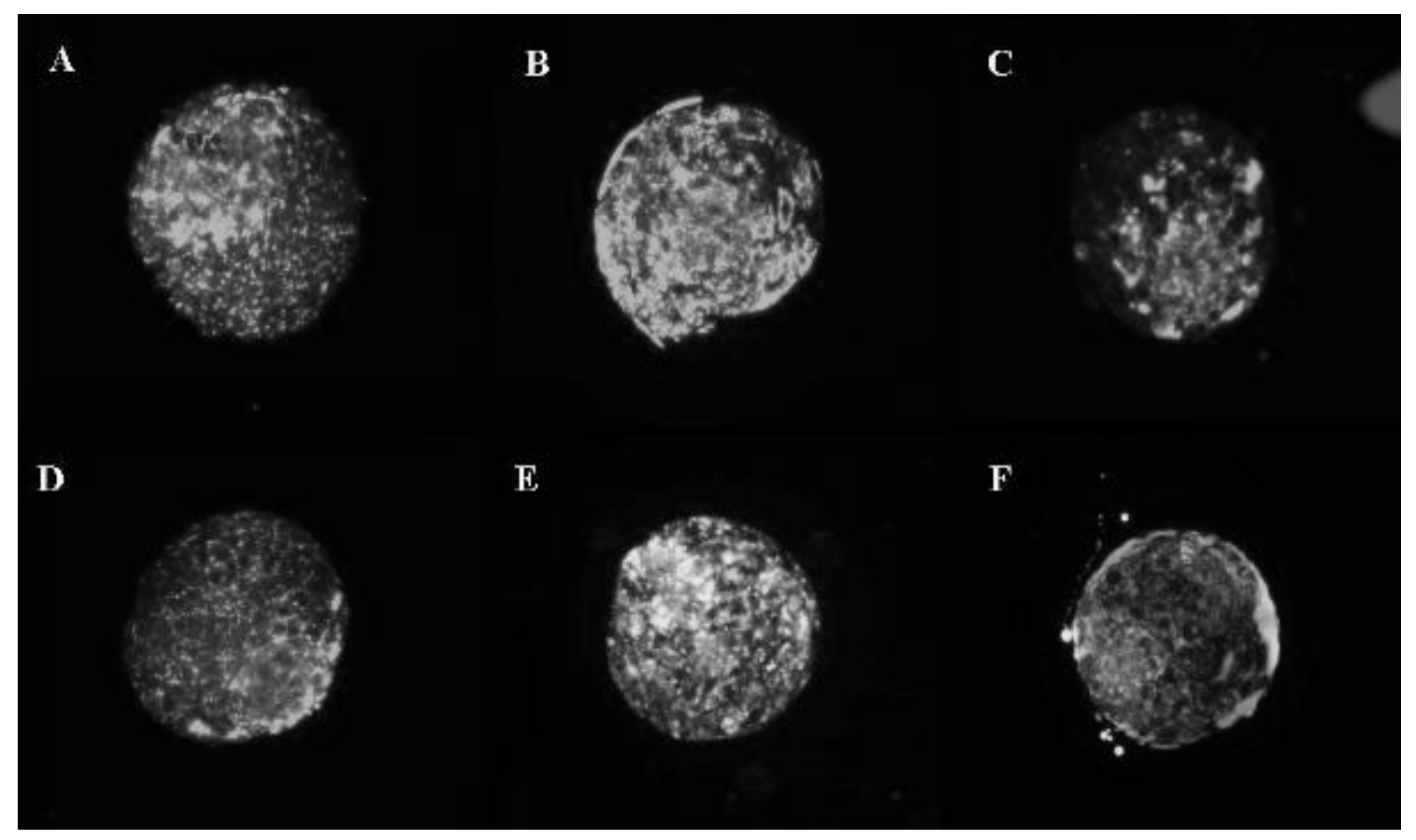

Figura 8. Fotomicrografia em epifluorescência do conteúdo lipídico pela técnica de Nile Red em blastocistos expandidos obtidos no oitavo dia de cultivo. A - Grupo controle; B - Grupo CLA; C - Grupo LA; D - Grupo EPA; E - DHA; F - Grupo Controle (objetiva de 40X). 


\section{Qualidade embrionária - re-expansão embrionária pós-criopreservação}

A taxa de re-expansão às 24 e 48 horas pós descongelamento e a taxa de eclosão variaram significativamente entre os tratamentos $(\mathrm{P}<0,05)$ como podemos observar na Tabela 4 , onde verificamos uma melhor sobrevivência in vitro nos grupos tratados com o ácido linoléico (conjugados ou não).

Quando analisamos a taxa de eclosão a partir dos blastocistos que sobreviveram à técnica de criopreservação os grupos tratados com LA e com CLA apresentaram uma taxa de eclosão similar ao que é observado em embriões produzidos in vitro a fresco $(51,44 \%$ e $50,40 \%$ de eclosão a fresco, tabela 1) e $(62,79 \%$ e $48,27 \%$ congelados/descongelados, tabela 4) respectivamente.

Tabela 4. Taxas de sobrevivência in vitro de blastocistos criopreservados e cultivados por 24 e 48 horas (taxa de re-expansão da blastocele) e taxa de eclosão em diferentes suplementações no meio de cultivo CR2 + SFB + BSA em atmosfera de $5 \%$ de $\mathrm{CO}_{2}$ em ar (CONTROLE, CLA, LA, EPA e DHA).

\begin{tabular}{ccccc}
\hline Grupos & $\begin{array}{c}\text { N. de } \\
\text { Embriões }\end{array}$ & $\begin{array}{c}\text { Re-expansão } \\
24 \mathrm{hs}\end{array}$ & $\begin{array}{c}\text { Re-expansão }{ }^{\mathrm{a}} \\
48 \mathrm{hs}\end{array}$ & $\begin{array}{c}\text { Taxa de }^{\mathrm{a}} \\
\text { Eclosão (D10) }\end{array}$ \\
\hline CONTROLE & 26 & $57,69 \pm 9,88 \%^{\mathrm{ab}}$ & $50,00 \pm 10,0 \%^{\mathrm{ab}}$ & $23,08 \pm 8,42 \%^{\mathrm{b}}$ \\
CLA & 29 & $68,97 \pm 8,71 \%^{\mathrm{a}}$ & $65,52 \pm 8,98 \%^{\mathrm{a}}$ & $48,27 \pm 9,44 \%^{\mathrm{a}}$ \\
LA & 43 & $76,74 \pm 6,51 \%^{\mathrm{a}}$ & $74,42 \pm 6,73 \%^{\mathrm{a}}$ & $62,79 \pm 7,45 \%^{\mathrm{a}}$ \\
EPA & 25 & $40,00 \pm 10,0 \% \mathrm{o}^{\mathrm{b}}$ & $24,00 \pm 8,71 \%^{\mathrm{b}}$ & $8,00 \pm 5,53 \%^{\mathrm{b}}$ \\
DHA & 40 & $37,51 \pm 7,75 \% \%^{\mathrm{b}}$ & $25,00 \pm 6,93 \%^{\mathrm{b}}$ & $0 \%{ }^{\mathrm{b}}$ \\
\hline
\end{tabular}

a: Dados dentro da mesma coluna apresentam diferença significativa $(\mathrm{P}<0,05)$

No gráfico 1, foi feita uma comparação entre as taxas dos embriões eclodidos dos diferentes grupos à fresco, e dos embriões que foram congelados/descongelados e voltaram para o cultivo in vitro por 72 horas. 


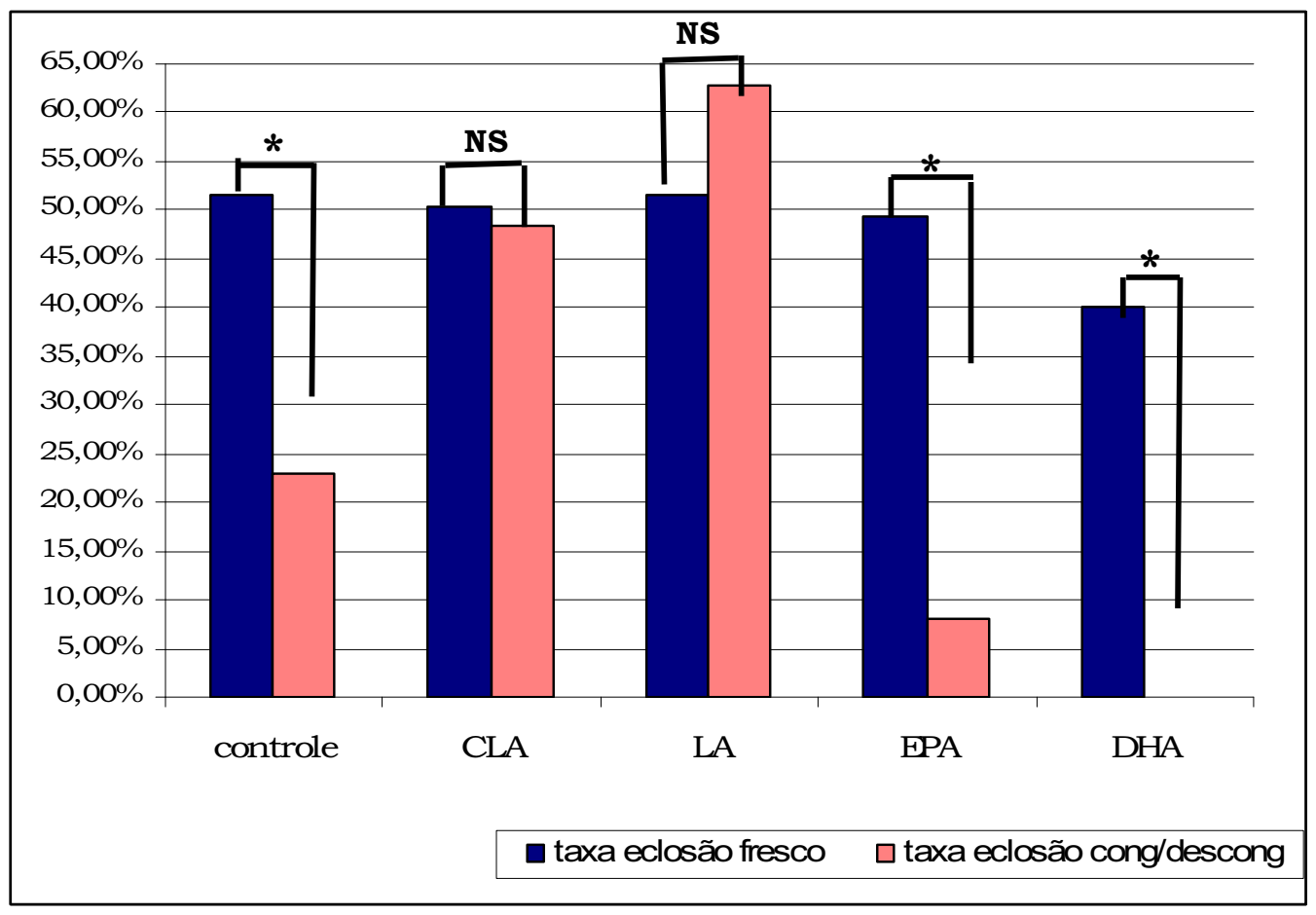

Gráfico 1 - Comparação entre as taxas de eclosão dos diferentes grupos quando avaliadas a fresco e pós-descongelamento. Onde há diferença estatística está identificado como $\left({ }^{*}\right)$, e onde não ocorre (NS).

\section{Qualidade embrionária - taxa de gestação}

O grupo tratado com CLA apresentou um aumento (embora não significativo) de $200 \%$ na taxa de gestação de embriões criopreservados em comparação ao grupo controle (Tabela 5 e gráfico 2). Este aumento está de acordo com os resultados de re-expansão e eclosão.

Apesar do pequeno número de embriões transferidos, uma análise menos rigorosa mostra que há uma tendência do grupo controle fresco resultar em taxa de eclosão melhor que o grupo controle congelado/descongelado $(\mathrm{P}=0,09)$ assim como o grupo tratado com EPA fresco resultar em taxa de eclosão melhor que o grupo tratado com EPA congelado/descongelado $(\mathrm{P}=0,053)$.

Comparando as taxas de gestação de embriões frescos e congelados tratados com CLA, não foi possivel observar diferença ou tendência $(p=0,23)$. Embora muito preliminar estes resultados juntamente com os resultados da taxa de 
eclosão sugerem um possivel efeito benéfico do CLA sobre a taxa de sobrevivência à criopreservação.

Tabela 5. Taxas de gestação de blastocistos criopreservados ou frescos transferidos para receptoras sincronizadas obtidos de diferentes suplementações no meio de cultivo (Controle, CLA e EPA).

\begin{tabular}{ccccccc}
\hline & \multicolumn{3}{c}{ Frescos } & & \multicolumn{3}{c}{ Congelados } \\
\cline { 2 - 7 } Grupos & TE & P 90 & \% P 90 a & TE & P 90 & \% P 90 a \\
\hline CONT & 23 & 5 & $22 \%$ & 20 & 1 & $5 \%$ \\
CLA & 21 & 5 & $24 \%$ & 20 & 3 & $15 \%$ \\
EPA & 21 & 7 & $33 \%$ & 20 & 2 & $10 \%$ \\
\hline
\end{tabular}

a: Dados dentro da mesma coluna apresentam diferença significativa $(\mathrm{P}>0,05)$

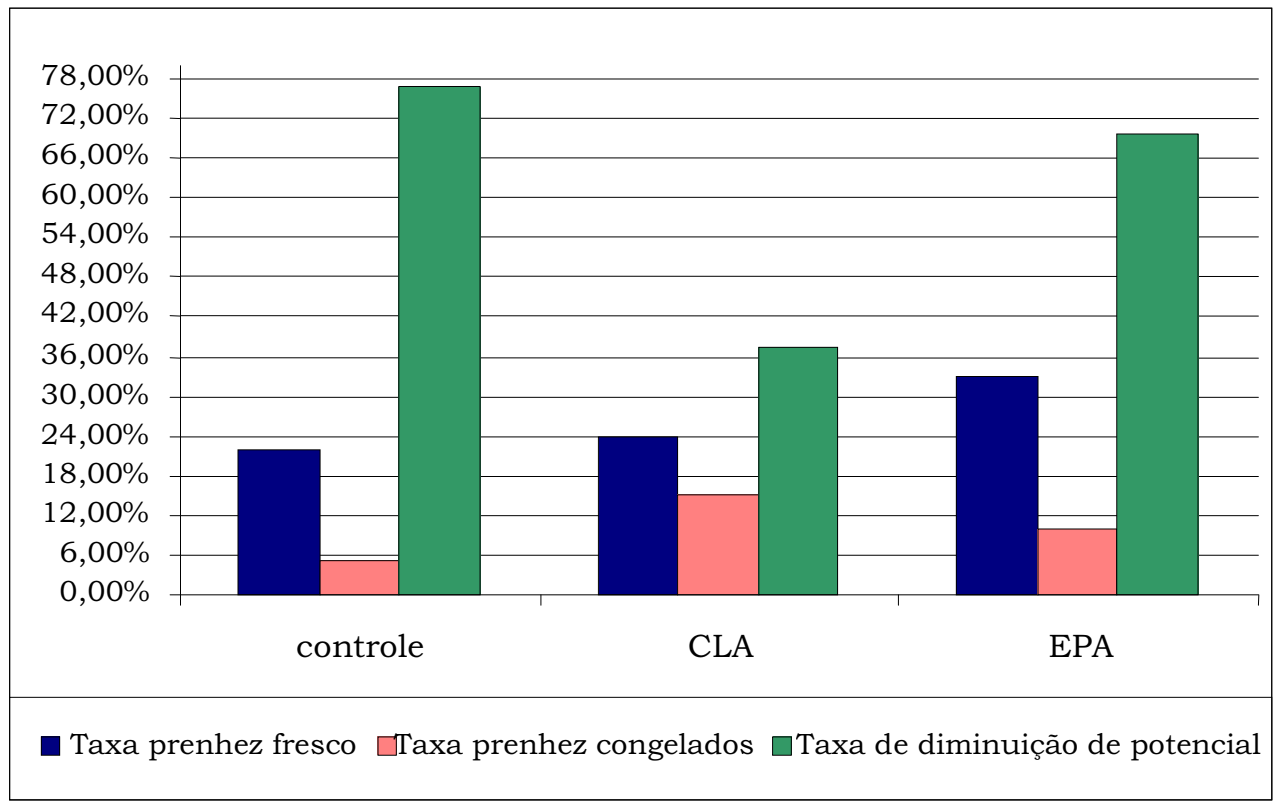

Gráfico 2. Taxas de gestação de blastocistos criopreservados ou frescos transferidos para receptoras sincronizadas, e suas respectivas taxas de diminuição do potencial de desenvolvimento. 


\subsection{DISCUSSÃO}

De um modo geral, a introdução dos ácidos graxos do grupo ômega-6 (CLA e LA) isoladamente no sistema de produção in vitro de embriões bovinos não interferiu negativamente, no entanto a taxa de sobrevivência póscongelamento foi significativamente melhor que o controle, comprovando a efeito positivo quando acrescentados à produção de embriões. Já os embriões produzidos com os ácidos graxos do grupo ômega-3 (EPA e DHA), apresentaram resultados muitas vezes inferiores ao controle, demonstrando que quando utilizados isoladamente na produção de embriões bovinos podem influenciar negativamente no processo. A relação entre $\Omega 3 / \Omega 6$ não foi avaliada, e estes ácidos graxos não foram colocados juntos no mesmo experimento. Dados atualizados da literatura demonstram que a relação entre $\Omega 3 / \Omega 6$ é muito importante em várias espécies, inclusive na saúde humana, sendo que o equilibro ideal indicado pela OMS (Organização Mundial Saúde) entre estes dois tipos de ácidos graxos é de $1 / 5$.

Em relação à taxa de clivagem, o grupo controle não diferiu dos tratamentos com ácidos graxos do grupo $\Omega 6$ (73,1\%; 69,5\%; 68,4\%, respectivamente controle, CLA e LA) e foi significativamente maior que a dos grupos tratados com $\Omega 3$ (68,3\%e $66,2 \%$, respectivamente para EPA e DHA).

No desenvolvimento embrionário até blastocisto, somente o grupo EPA $(27,7 \%)$ obteve resultados menores que os demais grupos testados (32\%; 34,7\%; 36,2\%; 30,3\%, que correspondem ao controle, CLA, LA e DHA), sendo que o grupo DHA não diferiu do EPA. Parte destes dados confirmam os resultados obtidos por Pereira et al. (2007, 2008a), que não apresentaram diferenças nas taxas de clivagem e blastocisto para os embriões produzidos com CLA e controle na presença de SFB.

Segundo Van Soon et al. (2001), o uso de óleo de silicone ou parafina nos meios de cultivo modificam o perfil lipídico dos embriões interferindo na sua sobrevivência ao congelamento. No presente estudo, não foi utilizado óleo no cultivo in vitro dos embriões, eliminando assim mais uma variável no processo. 
Conforme outros autores (LEIBO e LOSKUTOFF, 1993; HOCHI et al., 1996; SOMMERFELD e NIEMANN, 1999; FAIR et al., 2001; RIZOS et al., 2001; MASSIP et al., 1995) a sobrevivência de embriões in vitro congelados é reduzida, independente do sistema de cultivo utilizado, não só na comparação com os embriões in vivo, como também em relação aos seus pares não congelados. Diferente do que foi obtido nos resultados deste trabalho, onde a adição de ácidos graxos ômega 6 (CLA e LA) isoladamente ao sistema de cultivo com SFB melhoraram a sobrevivência dos embriões após o congelamento e descongelamento, corroborando com os dados de Pereira et al. $(2004,2007,2008$ a) em relação ao CLA. Sendo a taxa de eclosão dos embriões a fresco similar a dos congelados/descongelados. Neste estudo foram utilizados para o congelamento somente blastocistos expandidos grau I no dia $7^{\circ}$ de cultivo, pois de acordo com o trabalho de Sommerfeld e Niemann (1999) este estágio é o que apresenta melhores resultados.

A taxa de re-expansão da blastocele quando os embriões foram congelados/descongelados no trabalho de Pereira et al. (2007), houve uma diferença de $63,7 \%$ para o grupo CLA contra $34,7 \%$ do grupo controle. Comparando com os dados obtidos neste trabalho, a taxa de re-expansão da blastocele às 48horas, o controle obteve $50 \%$, o CLA $65,5 \%$ e o LA $74,4 \%$, e estes dados no entanto não apresentaram diferença estatística. Já os embriões produzidos com a suplementação de EPA e DHA, congelados/descongelados e também avaliados às 48horas, foram significativamente inferiores dos demais (24\% EPA e 25\% DHA). Segundo Pereira et al. (2008a) estes resultados são justificados pelo efeito da suplementação com CLA (t-10,c-12) em meios com soro reduzindo a deposição de lipídeos no citoplasma durante o cultivo e assim significativamente melhorando a resistência do embrião PIV à criopreservação.

Tominaga et al. (2000) utilizou LA em conjunto com a albumina (LAA) no meio e em atmosfera controlada de $5 \% \quad \mathrm{CO}_{2}, 5 \% \quad \mathrm{O}_{2}$ e $90 \% \mathrm{~N}_{2}$. Os resultados demonstraram que também não há um efeito negativo da adição dos ácidos graxos (LA desta vez conjugado com a albumina). Comparando a 
produção de embriões controle e o do grupo LAA sem passarem pelo processo de congelamento, não houve diferença $(59,8 \%$ x $75,5 \%$, respectivamente). Quando os embriões do grupo controle e LAA foram congelados/descongelados, houve diferença significativa, sendo que o grupo LAA apresentou uma taxa de eclosão de 43,3\% contra 15,2 \% do controle. Isso confirma que a adição de ácidos graxos, no caso o LAA, ao sistema de cultivo melhora a viabilidade pós-congelamento/descongelamento.

Segundo Hochi et al. (1999), a adição de 0,1\% de LAA em meio SOF com BSA para a produção de embriões bovinos em atmosfera controlada, melhorou a sobrevivência de mórulas pós-descongelamento (controle 32\% $\mathrm{x}$ LAA 60\%). Uma possível explicação seria que o aumento da sensibilidade ao congelamento é dada pela incorporação direta do LAA à membrana do embrião, modificando sua fluidez.

Laowtammthron et al. (2005) também adicionaram LAA ao cultivo de embriões bovinos, e após vitrificados a taxa de sobrevivência também foi maior para os embriões cultivados com LAA (80\%) em comparação ao controle $(56 \%)$.

Quando avaliada a qualidade dos embriões mediante a contagem de núcleos o grupo LA foi melhor que o $\operatorname{EPA}(147,74 \times 131,23$, respectivamente) e os demais grupos não diferiram entre si. No trabalho de Tominaga et al. (2000), a contagem de núcleos utilizando o LAA e controle não diferiu $(121,6$ x 121,5 frescos, e 93,0 x 91,2 congelados, respectivamente). Garcia (2004), obteve um número de núcleos contados para os meios suplementados com SFB de 122,7, e meios cultivados sem SFB de 126,8. Assim, de modo geral, a adição de ácidos graxos não interferiu no número de células, onde somente o grupo EPA obteve resultados menores que os demais. Estes resultados implicam que o aumento na taxa de sobrevivência nos grupos suplementados com ômega 6 não é mediado por um aumento no número de células.

$\mathrm{Na}$ técnica de coloração com o Nile Red, a quantidade de luz fluorescente emitida é correlacionada com o conteúdo lipídico. Ela é altamente sensivel e tem repetibilidade (FERGUNSON e LEESE, 1999; KIM et 
al., 2001) onde um único oócito ou embrião pode ser analisado (GENICOT et al., 2005). Existem outras técnicas para medir o conteúdo lipídico, como a cromatografia gasosa, o HPLC, corante Sudan Black, porém cada uma analisa apenas parte do embrião, ou há a necessidade de utilização de vários embriões para um único resultado.

A presença do soro no meio de cultivo de embriões acumula grandes gotas lipídicas e eletro densas, e seu conteúdo tem proporções significantes de triglicerídeos (ABE et al., 2002). Ferguson e Leese (1999), também relataram que o tipo de lipídeo mais acumulado durante o desenvolvimento de mórulas para blastocistos em culturas com SFB sãos os triglicerídeos.

Para Sata et al. (1999), o acúmulo é de ácidos graxos saturados de cadeia longa como o ácido palmítico e esteárico. Mas a importância das gotas de lipídeos nos oócitos e embriões de mamíferos ainda permanece com dados insuficientes.

Os resultados coletados de avaliação do conteúdo lipídico nos embriões não apresentaram diferenças significativas entre os grupos. Estes dados foram diferentes dos resultados obtidos por Pereira et al. (2007, 2008a) que afirmaram que o acúmulo de lipídeos é reduzido com a adição de CLA aos meios de cultivo com SFB. Os embriões neste caso foram classificados em magros, intermediários e gordos de acordo com as observações feitas sob microscópio aplicando a óptica de Nomarski.

Leroy et al. (2005), avaliaram o conteúdo lipídico de oócitos e embriões com o corante Nile red, onde foi possivel observar que mórulas cultivadas na presença de SFB emitiam uma maior quantidade de luz fluorescente que as cultivadas somente com a adição de BSA-FAF, e concluiram que a presença de SFB aumentou em 30\% a quantidade de gotas lipídicas.

Fergunson e Leese (1999) avaliaram o conteúdo de triglicerídeos em oócitos imaturos, maturados, embriões de duas células, e blastocistos cultivados com a presença ou ausência de SFB em atmosfera de $5 \% \mathrm{CO}_{2}, 5 \%$ $\mathrm{O}_{2}$ e $90 \% \mathrm{~N}_{2}$. A quantidade inicial nos oócitos é de 59ng, e depois da maturação in vitro passa para 46ng. Os embriões de duas células 
apresentaram 34ng, e os blastocistos eclodidos cultivados sem SFB mantiveram o valor próximo de triglicerídeos (33ng). Quando estes embriões foram cultivados na presença de soro, a quantidade de triglicerídeos foi de $62 \mathrm{ng}$, onde concluíram que os triglicerídeos podem servir como fonte de energia durante os estágios iniciais (maturação e fecundação), e a presença do SFB causou ou uma síntese excessiva ou um acúmulo excessivo de triglicerídeos nos estágios mais avançados. Pois tem sido relatado que culturas de células de mamíferos facilmente incorporam os ácidos graxos do meio de cultivo.

Em humanos (HAGGARTY et al., 2006), foram utilizados ácidos graxos marcados com $\mathrm{C}^{13}$, e estes após duas horas de cultivo com embriões de 8 células, foram incorporados nos triglicerídeos e nos fosfolipídeos. Embriões que de desenvolvem além do estágio de 4 células, possuem significativamente maiores concentrações de ácidos graxos insaturados e menores de saturados. Eles também concluíram que o ácido linoléico é mais importante nos estágios finais de desenvolvimento, e o acido palmítico nos estágios iniciais. O ácido linoléico estimula a proteína Kinase C que é crítica no crescimento celular e diferenciação, e é o acido graxos que tem sido mais utilizado nos estudos de fertilidade animal.

Segundo Mersmann et al. (2001), as respostas do CLA podem diferir entre as espécies devido ao padrão do metabolismo ser espécie-específico, tornando assim, a comparação de resultados delicada. É o mesmo que diz Pereira et al. (2008a), que o mecanismo de ação do trans-10, cis-12CLA não é totalmente esclarecido e os estudos in vitro e in vivo não estão sempre de acordo, possivelmente porque isômeros de CLA atuam em diferentes caminhos e com diferentes conseqüências quando administrados para diferentes espécies.

Durante este estudo, foi desenvolvido um experimento piloto utilizando atmosfera controlada de $5 \% \quad \mathrm{CO}_{2}, 5 \% \quad \mathrm{O}_{2}$ e $90 \% \mathrm{~N}_{2}$ onde os embriões tiveram suas células do cumulus totalmente removidas, e foram testados somente os grupos controle, CLA e LA suplementados com $1 \%$ de SFB. Paralelamente a este experimento, outros embriões foram produzidos 
como no processo padrão (5\% $\mathrm{CO}_{2}$ em ar e com células do cumulus). No oitavo dia de cultivo foi avaliada a quantidade de lipídeos dos embriões nas duas atmosferas testadas. A quantidade de lipídeos medida pela intensidade de fluorescência foi diferente estatisticamente dentro do grupo LA, ou seja, os embriões produzidos com a adição de LA em atmosfera controlada apresentaram uma menor quantidade de lipídeos que os embriões do mesmo grupo produzidos em atmosfera de $5 \% \mathrm{CO}_{2}$ em ar. Os embriões do grupo CLA e do controle também apresentaram uma redução na quantidade de lipídeos quando a atmosfera de $\mathrm{O}_{2}$ foi reduzida para $5 \%$, mas esta não foi significativa. Este resultado indica que um possivel fator para a diminuição na quantidade de lipídeos dos embriões seria a produção destes em atmosfera controlada. Este pode ser um caminho a ser seguido, utilizando somente os grupos com melhores taxas de re-expansão pósdescongelamento (CLA e LA) agora em atmosfera controlada, para produzir embriões, congelá-los e descongelá-los e transferi-los para receptoras sincronizadas. Além da tentativa válida de se fazer um experimento utilizando uma proporção entre a quantidade de ômega 3/ ômega 6 utilizada.

Quando avaliamos a taxa de gestação aos 90 dias, os grupos de embriões frescos apresentaram uma produção similar, sem diferenças significativas, assim como os transferidos após serem descongelados. Todavia, pôde ser observado que os embriões do grupo controle obtiveram uma diminuição de $77 \%$ no seu potencial de desenvolvimento e o grupo tratado com EPA apresentou uma diminuição de 69,7\%. Somente o grupo tratado com CLA, no entanto, apresentou uma diminuição menor do potencial, de apenas $37,5 \%$. Isso pode sugerir que de alguma forma, a presença do CLA melhorou a sobrevivência pós-congelamento.

Para Diez et al. (2001), quando o embrião passa pelo processo de delipidação altera o seu potencial de desenvolvimento, sugerindo que o armazenamento ou o estoque de lipídeos herdado maternalmente interfere na recuperação metabólica pós-descongelamento. A sobrevivência in vitro foi melhor após a delipidação, porém as transferências destes embriões resultam em taxas de prenhezes muito baixas. 
No presente estudo, foi obtido um aumento na viabilidade do embrião (taxa eclosão) pós-descongelamento de embriões tratados com os ácidos graxos do grupo ômega 6 . A quantidade total de lipídios não foi modificada, e não houve perdas na taxa de gestação em comparação com o grupo controle, sendo assim, a adição destes não apresenta um efeito negativo na taxa de gestação.

Em resumo, embriões tratados com os ácidos graxos do grupo ômega 6 (LA e CLA) apresentaram melhores resultados quando os embriões foram submetidos à técnica de congelamento. Estes resultados aparentemente não foram gerados pelo aumento de velocidade de clivagem, da diminuição da morte celular (número de núcleos) e tampouco pela variação da quantidade total de lipídeos (Nile Red). Sendo assim, a hipótese mais provável é que os ácidos graxos atuem modificando a composição de lipídeos das membranas dos embriões, influenciando na sua fluidez que é de grande importância quando trabalhamos com criopreservação celular.

\subsection{RESUMO DOS RESULTADOS}

- A adição de ácidos graxos do grupo ômega 6 (LA e CLA) na produção de embriões bovinos in vitro não diferiu do controle na taxa de clivagem e na taxa de blastocistos indicando que a adição destes não influência negativamente o processo

- Já no grupo ômega 3 (EPA e DHA) a taxa de clivagem foi inferior ao controle, e a taxa de blastocisto somente o EPA foi inferior quando comparado ao controle, indicando um influência negativa deste grupo quando adicionados isoladamente no processo de produção

- Quando foi avaliada a taxa de eclosão dos embriões à fresco e a quantidade de lipídeos pela técnica do Nile Red, todos os ácidos graxos testados não apresentaram diferenças significativas 
- Na contagem de núcleos, o LA foi significativamente melhor que o grupo EPA, e os demais grupos não diferiram entre si

- Quando os embriões passaram pelo processo de congelados/descongelados, tanto a taxa de re-expansão da blastocele às 48 horas de cultivo como a de eclosão foram significativamente melhores para os ácidos graxos do grupo ômega 6 (LA e CLA), indicando uma possível melhoria que a adição de LA e CLA isoladamente ao meio de cultivo

- Os grupos controle, CLA e EPA foram submetidos a avaliação in vivo, onde foram transferidos para receptoras sincronizadas. A taxa de gestação aos 90 dias tanto dos embriões frescos, como dos que foram congelados e descongelados não diferiram estatisticamente, mas foi observado que o grupo CLA apresentou um aumento de $200 \%$ em comparação ao controle na taxa de gestação depois de descongelados. Mas o número de transferências foi pequeno, e é preciso mais repetições para a comprovação destes dados

- De forma geral, foi comprovada que a adição de CLA e LA na produção de embriões bovinos in vitro em meio suplementado como SFB e em atmosfera de $5 \% \mathrm{CO}_{2}$ em ar com co-cultura apresentaram melhores resultados quando os embriões foram submetidos à técnica de congelamento.

\subsection{CONCLUSOES E PERSPECTIVAS}

- A suplementação com CLA e LA na produção de embriões aumentou a criotolerância, no entanto, este efeito não foi mediado por uma diminuição no conteúdo total de lipídeos, e tampouco por um aumento no número de células

- No experimento piloto, a atmosfera de 5\% $\mathrm{CO}_{2}, 5 \% \quad \mathrm{O}_{2}$ e $90 \% \mathrm{~N}_{2}$, influenciou na diminuição da quantidade total de lipídeos e isso poderia nos 
levar a confirmação de que a utilização de ácidos graxos do grupo ômega 6 (CLA e LA) em meios suplementados com soro e em atmosfera controlada poderiam resultar em embriões mais capazes de sobrevivência póscongelamento/descongelamento

- Outros estudos devem ser desenvolvidos para comprovar o efeito do aumento da criotolerância e melhorias nas taxas de gestações em embriões produzidos in vitro pós-congelamento/descongelamento, e para avaliar a modificação na composição dos lipídeos dos embriões, tanto dos lipídeos presentes na forma de estoque de energia como os presentes nas membranas, e sua relação com o sucesso no congelamento. 

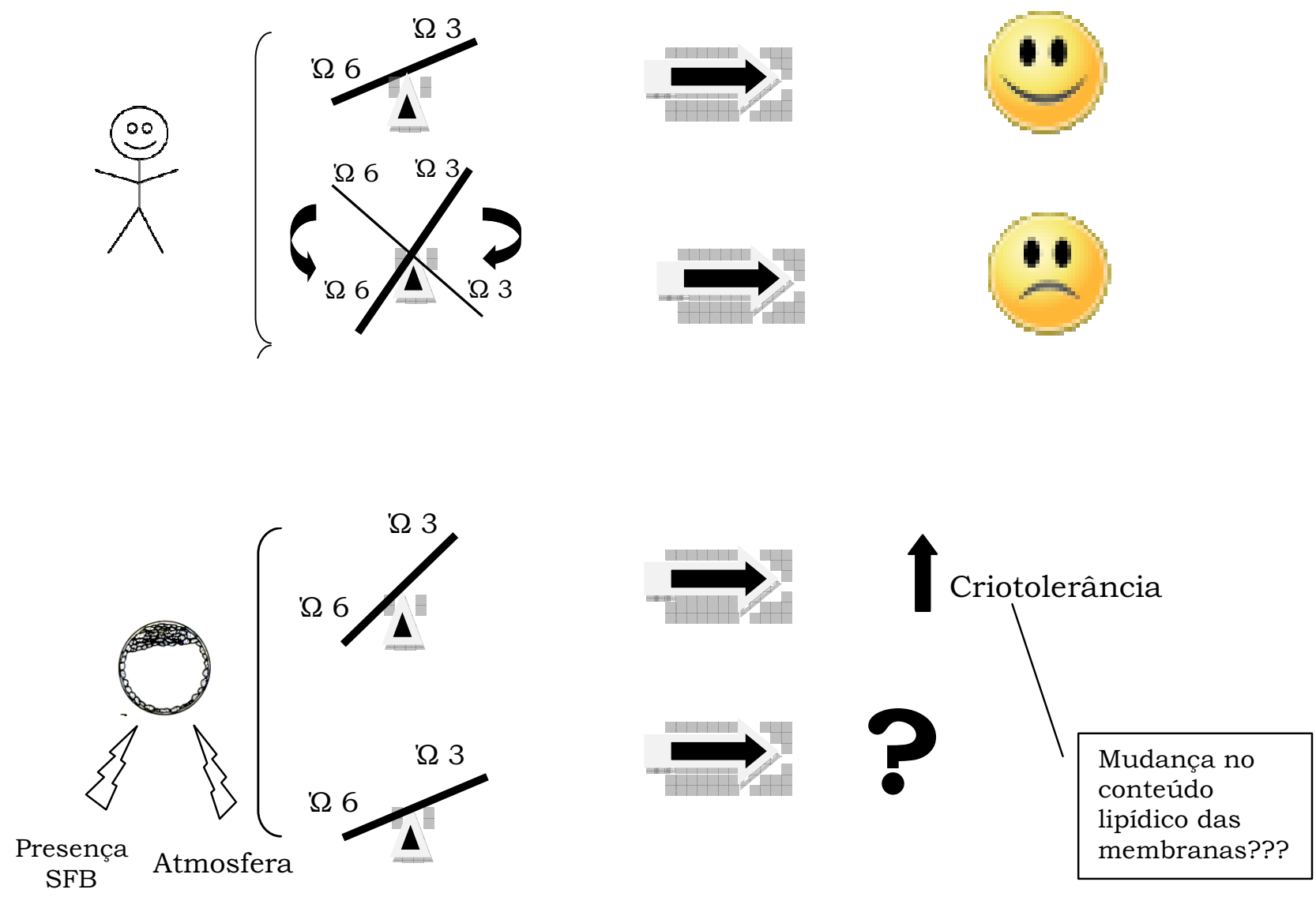

Modelo Hipotético da possível relação entre a adição de ácidos graxos em cultura de embriões bovinos e uma comparação ao que acontece na saúde humana e animal.

Em humanos, quando não há um balanço ideal na relação entre ômega 3/ômega 6 na alimentação, ocorre uma propensão a uma séries de doenças. Em cultura de embriões foi visto que um aumento na quantidade do ômega 6 no meio de cultivo celular melhorou a taxa de sobrevivência à criopreservação. Não foi observada uma mudança na quantidade de lipídeos nos embriões e nem aumento no seu número de células. Assim, uma possível hipótese seria que houve uma influência do ácido graxo ômega 6 nas membranas, talvez mediada pela sua incorporação, e isto aumentou a quantidade de ácidos graxos poliinsaturados presentes nesta ocasionando um efeito positivo na fluidez, e conseqüentemente deixando o embrião mais estável para o congelamento. É sabido que a atmosfera gasosa e a suplementação de soro fetal bovino no meio de cultivo influenciam a produção e a qualidade dos embriões. Nos cultivos na presença de SFB não é possivel investigar a quantidade exata de cada um dos ácidos graxos presentes no meio, pois neste há diferentes ácidos graxos e outros constituintes que modificam e influenciam essa relação. Assim, a proporção entre ômega 3/ômega 6 não é sabida. É possível que o controle da concentração exata de ácidos graxos adicionados ao meio de cultivo na relação recomendada à saúde humana de $1 / 5$ resulte em uma influência positiva na sobrevivência pós-descongelamento embrionário. 


\section{REFERÊNCIA BIBLIOGRÁFICA}

ABD EL RAZEK, I.M.; CHARPIGNY,G.; KODJA, S.; MARQUANT-LEGUIENNE, B.; MERMILLOD, P.; GUYADER-JOLY, C. Differences in lipids composition between in vivo and in vitro produced bovine embryos. Theriogenology, v. 53, 2000 (abstr).

ABE, H.; HOSHI, H. Evaluation of bovine embryos produced in high performance serum-free media. Journal Reproduction Development, v. 49,p. 193-202, 2003.

ABE, H.; YAMASHITA, S.; ITOH, T.; SATOH, T.; HOSHI, H. Ultrastructure of bovine embryos developed from in vitro - matured and fertilized oocytes: comparative morphological evaluation of embryos cultured either in serum free medium or in serum supplemented medium. Molecular Reproduction Development, v. 53, p. 325-335, 1999.

ABE, H.; YAMASHITA, S.; SATOH, T.; HOSHI, H. Accumulation of cytoplasmic lipid droplets in bovine embryos and cryotolerance of embryos developed in different culture systems using serum-free or serum-containing media. Molecular Reproduction Development, v. 61, p. 57-66, 2002.

ADLER, V.; YIN, Z.; TEW, K.D.; RONAI, Z. Role of redox potential and reactive oxygen species in stress signaling. Oncogene, v. 18, p. 6104-6111, 1999.

ANASH, G.A. and BUCKLAND, R.B. Genetic variation in fowl semen cholesterol and phospholipid levels, and the relationships of these lipids with fertility of frozen-thawed and fresh semen. Poultry Science, v. 61, p. 623$637,1994$. 
ARAV, A.; ZERON, Y.; LESLIE, S.B.; BEHBOODI, E.; ANDERSON, G.B.; CROWE, J.H. Phase transition temperature and chilling sensitivity of bovine oocytes. Cryobiology, v. 33, 589-599, 1996.

AUSTIN, C.R. Observations on the penetration of the sperm into the mammalian egg. Austr. J. Sci. Res., v. 134, p. 581, 1951.

BAVISTER, B.D. Culture of preimplantation embryo: facts and artifacts. Human Reproduction, v. 1, p. 91-148, 1995.

BAUNGARD, L.H.; CORL, B.A.; DWYER, D.A.; BAUMAN, D.E. Effects of conjugated linoleic acids (CLA) on tissue response to homeostatic signals and plasma variables associated with lipid metabolism in lactating dairy cows. Journal of Animal Science, v.80, p. 1285-1293, 2002.

BRACKETT, B.G.; BOUSQUET, D.; BOICE, M.L.; DONAWICK, W.J.; EVANS, J.F.; DRESSEL, M.A. Normal development following in vitro fertilization in the cow. Biology of Reproduction, v.27, p.147-158, 1982.

BROWN, J.M.; HALVORSEN, Y.D.; LEA-CURRIE, Y.R.; GEIGERMAN, C.; McINTOSH, M. Trans-10, cis-12 but not cis-9, trans-11, Conjugated linoleic acid attenuates lipidogenesis in primary cultures of stromal vascular cells from human adipose tissue. Journal of Nutrition, v. 131, p. 2316-2321, 2001.

CAROLAN, C.; LONERGAN, P.; VAN LANGENDONCKT, A.; MERMILLOD, P. Factors affecting bovine embryo development in synthetic oviduct fluid following oocyte maturation and fertilization in vitro. Theriogenology, v. 43, p. 1115-1128, 1995.

CHANG, M.C. Fertilizing capacity of spermatozoa deposited into the Fallopian tubes. Nature, v. 168, p. 697-698, 1951. 
CHANG, M.C. Fertilization of rabbit ova in vitro. Nature, v.184, p.466-467, 1959.

CHARPIGNY, G.; GUESNET, P.; MARQUANT-LEGUIENNE, B.; HEYMAN, Y.; MERMILLOD, P.; HUMBLOT, P. Fatty acid composition of trglycerides, phosphatidylcholines and phosphatidylethanollamines of bovine embryos. Les Actes du BRG, v. 4, p. 159-172, 2003.

CHO, S.R.; CHO, S.K.; LEE, S.L.; CHOE, S.Y.; RHO, G.J. Enhanced cryosurvival of bovine blastocysts produced in vitro in serum free medium. Journal Assist Reproduction Genetic, v. 19, p. 487-492, 2002.

DE AZAMBUJA, R.M.; WATANABE, Y.F.; PERIPATO, A.C.; WATANABE, M.R.; VILA, R.A.; VERSIANI, A.; MENDES, F.C.; LOBO, R.B. Primeiras prenhezes do Brasil utilizando fecundação in vitro em vacas Nelore PO. Arq. Fac. Vet. UFRGS, v.24, p. 234, 1996.

DE BEM, A.R.; RUMP, R.; LUNA, N.M.; OFUGI, K.; COELHO, J.; AVELINO, M. Banco brasileiro de germoplasma animal. In: CONGRESSO BRASILEIRO DE REPRODUÇÃo ANIMAL, Belo Horizonte. Anais, p. 89-97, 1995.

DE PAZ, P.; SANCHEZ, A.J.; FERNANDEZ, J.G.; CARBAJO, M.; DOMINGUEZ, J.C.; CHARMORRO, C.A.; ANEL, L. Sheep embryos cryopreservation by vitrification and conventional freezing. Theriogenology, v. 42, p. 327-338, 1994.

DIEZ, C.; HEYMAN,Y.; LE BOURHIS, D.; GUYADER-JOLY, C.; DEGROUARD, J.; RENARD, J.P. Delipidating in vitro produced bovine zygotes: effect on further development and consequences for freezability. Theriogenology v. 55, p. 923-936, 2001.

DIEZ, C.; LE BOURHIS, D.; HEYMAN, Y.; RENARD, JP. Effect of partial lipid removal from in vitro produced bovine zygotes on further development in vitro 
and on the freezing tolerance of blastocysts. Theriogenology v. 45, p.166, 1996.

DOBRINSKY, J.R. Cellular approach to cryopreservation of embryos. Theriogenology, v. 45, p. 17-26, 1996.

DROBNIS, E.Z.; CROWE, L.M.; BERGER, T.; ANCHORDOGUY, T.J.; OVERSTREET, J.W.; CROWE, J.H. Cold chock damage is due to lipid phasetransitions in cell-membranes - a demonstration using sperm as a model. The Journal of Experimental Zoology, v. 265, p. 432-437, 1993.

DUMOULIN, J.C.; MEIJERS, C.J.; BRAS, M.; COONEN, E.; GERAEDTS, J.P.; EVERS, J.L. Effect of oxygen concentration on human in vitro fertilization and embryo culture. Human Reproduction, v. 14, p. 465-469, 1999.

EVANS, M.; PARK,Y.; PARIZA, M.W.; CURTIS, L.; KUEBLER, B.; McINTOSH, M. Trans-10,cis-12 conjugated linoleic acid reduces triglyceride content while differentially affecting peroxisome proliferators activated receptor $\gamma 2$ and aP2 expression in 3T3-L1 preadipocytes. Lipids, v. 36, p. 1223-1232, 2001.

ECKERT, J.; NIEMANN, H. In vitro maturation, fertilization and culture to blastocysts of bovine oocytes in protein free media. Theriogenology, v. 43, p. 913-926, 1995.

FAHY, G.M.; MACFARLANE, D.R.; ANGELL, C.A.; MERYMAN, H.T. Vitrification as an approach to cryopreservation. Cryobiology, v. 21, p. 407426, 1984.

FARIN, P.W.; CROSIER, A.E.; FARIN, C.E. Influence of in vitro systems on embryo survival and fetal development in cattle. Theriogenology, v. 55, p. 151-170, 2001. 
FAIR, T.; LONERGAN, P.; DINNYES, A.; COTTELL, D.C.; HYTTEL, P.; WARD, F.A.; BOLAND, M.P. Ultrastructure of Bovine Blastocysts following Cryopreservation: Effect of Method of Blastocyst Production. Molecular Reproduction Development, v. 58, p. 186-195, 2001.

FERGUNSON, E.M. \& LEESE, H.J. Triglyceride content of bovine oocytes and early embryos. Journal of Reproduction and Fertility, v. 116, p. 373378, 1999.

FUJITANI, Y.; KASAI, K.; OHTANI, S.; NISHIMURA, K.; YAMADA, M.; UTSUMI, K. Effect of oxygen concentration and free radicals on in vitro development of in vitro-produced bovine embryos. Journal Animal Science, v. 75, p. 483-489, 1997.

FUKUI, Y.; MCGOWAN, L.T.; JAMES, R.W.; PUGH, P.A.; TERVIT, H.R. Factors affecting the in vitro development to blastocysts of bovine oocytes matured and fertilized in vitro. Journal of Reproduction and Fertility, v. 92, p. 125-131, 1999.

FUKUDA, Y.; ICHIKAWA, M.; NAITO, K.; TOYODA, Y. Birth of normal calves resulting from bovine oocytes matured, fertilized and cultured with cumulus cells in vitro up to the blastocyst stage. Biology Reproduction, v. 42, p. 114$119,1990$.

GARCIA, S.M. Bloqueio e morte celular programada em embriões bovinos: efeitos da fonte de suplementação protéica e da cinética do desenvolvimento. Pirassununga, 2004, 65p. Dissertação de Mestrado. Faculdade de Zootecnia e Engenharia de Alimentos - Universidade de São Paulo.

GENICOT, G.; LEROY, J.L.M.R.; VAN SOOM, A.; DONNAY, I. The use of a fluorescent dye, Nile red, to evaluate the lipid content of single mammalian oocytes. Theriogenology, v. 63, p. 1181-1194, 2005. 
GRANLUND, L.; PEDERSEN, J.I.; NEBB, H.I. Impaired lipid accumulation by trans-10, cis-12 CLA during adipocyte differentiation is dependet on timing and length of treatment. Biochimica et Biophysica Acta, 1687, p. 11-22, 2005.

GRANLUND, L.; JUVET, L.K.; PEDERSEN; J.I.; NEBB, H.I. Trans-10, cis-12 Conjugated linoleic acid prevents tryacyl glycerol accumulation in adipocytes by acting as a PPAR $\gamma$ modulator. Journal of Lipid Research, v. 44, p. 14411452, 2003.

GUERIN, P.; MOUATASSIN, S.; MÉNÉZO, Y. Oxidative stress and protection against reactive oxygen species in the pre-implantation embryo and its surroundings. Human Reproduction Update, v.7, p. 175-189, 2001.

GUR, M.I.; HARWOOD, J.L. Lipid Biochemystry: An Introduction. London: Chapman and Hall, p. 406, 1991.

HAGGARTY, P.; WOOD, M.; FERGUSON, E.; HOAD, G.; SRIKANTHARAJAH, A.; MILNE, E. Fatty acid metabolism in human preimplantation embryos. Human Reproduction, v. 21, n. 3, p. 766-773, 2006.

HASLER, J.F.; HENDERSON, W.B.; HURTGEN, P.J.; JIN, Z.Q.; MC CAULEY, A.D.; MOYER, S.A.; NEELY, B.; SHUEY, L.S.; STOKES, J.E.; TRIMMER, S.A. Production, freezing and transfer of bovine IVF embryos and subsequent calving results. Theriogenology, v. 43, p. 141-152, 1995.

HASLER, J.F. The current status of oocytes recovery, in vitro embryo production, and embryo transfer in domestic animals, with an emphasis on the bovine. Journal Animal Science, v. 76 (supppl. 3), p. 52-74, 1998.

HASLER, J.F.; HURTGEN, P.J.; JIN, Z.Q.; STOKES, J.E. Survival of IVFderived bovine embryos frozen in glycerol or ethylene glycol. Theriogenology, v. 48, p. 563-579, 1997. 
HOCHI, S.; KIMURA, K.; HANADA, A. Effect of linoleic acid-albumin in the culture medium on freezing sensitivity of in vitro-produced bovine morulae. Theryogenology, v. 52, p. 497-504, 1999.

HOCHI, S.; SEMPLE, E.; LEIBO, S.P. Effect of cooling and warming rates during cryopreservation on survival of in vitro-produced bovine embryos. Theriogenology, v. 46, p. 837-847, 1996.

HYTTEL, P.; NIEMANN, H. Ultrastructure of porcine embryos following development in vitro versus in vivo. Molecular Human Reproduction, v. 27, p. $136-144,1990$.

IMAI, K.; KOBAYASHI, S.; GOTO, Y.; DOCHI, O.; SHIMOHIRA, I. Cryopreservation of bovine embryos obtained by in vitro culture of IVM-IVF oocytes in the presence of linoleic acid albumin. Theriogenology, v. 47: 347, 1997.

IWASAKI, S.; HAMANO, S.;KUWAYAMA, M.; YAMASHITA, M.; USHIJIMA, H.; NAGAOKA, S.; NAKAHARA, T. Dvelopmental changes in the incidence of chromossome anomalies of bovine embryos fertilized in vitro. J. Exp. Zool., v. 261: 79-85, 1992.

JOSE, A.A.F.B.V. Efeito do acido linoleico conjugado trans-10, cis-12 na regulação da lipogenese e expressão gênica em culturas de tecido adiposo de suínos em crescimento. Piracicaba, 2005, 60p. Tese de doutorado. Escola Superior de Agricultura "Luiz de Queiroz" - Universidade de São Paulo.

JOLY, T.; NIBART, M.; THIBIER, M. Hyaluronic acid as a substitute for proteins in the deep freezing of embryos from mice and sheep: an in vitro investigation. Theriogenology, v. 37, p. 473-480, 1992. 
KAIDI, S.; BERNARD, S.; LAMBERT, P.; MASSIP, A.; DESSY, F.; DONNAY, I. Effect on conventional controlled-rate freezing and vitrification on morphology and metabolism og bovine blastocyst produced in vitro. Biology of Reproduction, v.65, p. 1127-1134, 2001.

KAIDI, S.; DONNAY, I.; BRALION, V.; MASSIP, A.; DESSY, F. Comparison of two co-culture systems for the assessment of bovine blastocyst survival after cryopreservation. Journal of Reproduction Fertility, Abstract series 18, p. 98, 1996.

KAIDI, S.; DONNAY, I.; LAMBERT, P.; DESSY, F.; MASSIP, A. Osmotic behavior of in vitro produced bovine blastocysts in cryoprotectant solutions as a potential predictive test of survival. Cryobiology, v.41,n. 1, p. 106-115, 2000 .

KAIDI, S.; VAN LANGENDOCKT, A.; MASSIP, A.; DESSY, F.; DONNAY, I. Cellular alteration after dilution of cryoprotective solutions used for the vitrification of in vitro-produced bovine embryos. Theriogenology, v.52, n. 3, p. 515-525, 1999.

KARJA, N.W.K.; OTOI, T.; WONGSRIKEAO, P.; MURAKAMI, M..; AGUNG, B.; FAHRUDIN, M.; NAGAI, T. In vitro development and post-thaw survival of blastocysts derived from domestic cats. Theriogenology, v. 65, p. 415-423, 2006.

KEPPLER, C.R.; IRNOS, K.P.; McNEILL, J.J.; TOVE, S.B. Intermediates and products of the biohydrogenation of linoleic acid by Butyrinvibrio fibrisolvens. Journal of Biological Chemistry, v. 241: 1350-1354, 1966.

KESKINTEPE, L.; BRACKETT, B.G. In vitro developmental competence of in vitro-matured bovine oocytes fertilized and cultured in completely defined media. Biology Reproduction, v. 55, p. 333-339, 1996. 
KIM, J.Y.; KINOSHITA, M.; OHNISHI, M.; FUKUI, Y. Lipid and fatty acid analysis of fresh and frozen-thawed immature and in vitro matured bovine oocytes. Reproduction, 122, 131-138, 2001.

KHURANA, N.K.; NIEMANN, H. Energy metabolism in preimplantation bovine embryos derived in vitro or in vivo. Biology Reproduction, v. 62, p. 847-856, 2000a.

KHURANA, N.K.; NIEMANN, H. Effects of oocyte quality, oxygen tension, embryo density, cumulus cells and energy substrates on cleavage and morule/blastocyst formation of bovine embryos. Theriogenology, v.54, n. 5, p. 741-756, $2000 b$.

KHURANA, N.K.; NIEMANN, H. Effects of cryopreservation on glucose metabolism and survival of bovine morulae and blastocysts derived in vitro or in vivo. Theriogenology, v.54, n. 2, p. 313-326, 2000c.

KUWAYAMA, M.; FUJIKAWA, S.; NAGAI, T. Ultrastructure of IVM-IVF bovine blastocysts vitrified after equilibration in Glycerol 1,2-propanodiol using 2step and 16-step procedures. Cryobiology, v.31, n. 5, p. 415-422, 1994.

LAOWTAMMATHRON, C.; LORTHONGPANICH, C.; KETUDAT-CAIRNS, M.; HOCHI, S.; PARNPAI, R. Factors affecting cryosurvival of nuclear-transferred bovine and swamp buffalo blastocysts: effects of hatching stage, linoleic acid-albumin in IVC medium and ficoll supplementation to vitrification solution. Theriogenology, v. 64, p. 1185-1196, 2005.

LEIBFRIED-RUTLEDGE, M.L. Factors determining competence of in vitro produced cattle embryos. Theriogenology, v.51, p.473-485, 1999.

LEIBO, S.P. Commercial production of pregnancies from one step diluted frozen-thawed bovine. Theriogenology, v.25, p.166, 1986. 
LEIBO, S.P. Techniques for preservation of mammalian germ plasm. Animal Biotchnology, v. 3, p. 139-153, 1992.

LEIBO, S.P. Cryopreservation of oocytes and embryos: optimization by theoretical versus empirical analysis. Theriogenology, v. 69, p. 37-47, 2008.

LEIBO, S.P.; LOSKUTOFF, N.M. Cryobiology of in vitro derived bovine embryos. Theriogenology, v.39, p.81-94, 1993.

LEIBO, S.P.; ODA, K. High survival of mouse zygotes and embryos cooled rapidly or slowly in ethylene glycol plus polyvinylpyrrolidone. Cryo-letters, v. 14, p. 133-144, 1993.

LEIBO, S.P.; POLLARD, J.W.; MARTINO, A. Chilling and freezing sensitivity of "reassembled" in vitro-derived bovine embryos. Theriogenology, v. 43, p. 265, 1995 (abstr).

LEROY, J.L.M.R.; GENICOT, G.; DONNAY, I.; VAN SOOM, A. Evaluation of the lipid content in bovine oocytes and embryos with Nile red: a practical approach. Reproduction Domestic Animal, v.40, p.76-78, 2005.

LIM, K.T.; JANG, G.; KO, K.H.; LEE, W.W.; PAARK, H.J.; KIM, J.J.; LEE, S.H.; HWANG, W.S.; LEE, B.C.; KANG, S.K. Improved in vitro bovine embryo development and increased efficiency in producing viable calves using defined media. Theriogenology, v. 67, p. 293-302, 2007.

LIU, L.; TRIMARCHI, J.R.; NAVARRO, P.; BLASCO, M.A.; KEEFE, D.L. Oxidative stress contributes to arsenic-induced Telomere sttrition, chromossome instability and apoptosis. Journal of Biological Chemistry, v. 26, p. 31998-32004, 2003.

LÔBO, R.B. Programa de Melhoramento genético da raça Nelore. 3. ed. Ribeirão Preto: PMGRN, p. 104, 1996. 
LONERGAN, P.; FAIR, T.; CORCORAN, D.; EVANS, A.C.O. Effect of culture environment on gene expression and developmental characteristics in IVFderived embryos. Theriogenology, v. 65, p. 137-152, 2006.

LONERGAN, P.; KHATIR, H.; PIUMI, F.; RIEGER, D.; HUMBLOT, P.; BOLAND, M.P. Effect of time interval from insemination to firt cleavage on the developmental characteristics, sex ratio and pregnancy rate after transfer of bovine embryos. Journal of Reproduction and Fertility, Sep., 117 (1), p.159-167, 1999.

LONERGAN, P.; RIZOS, D.; GUTIERREZ-ADAN, A.; FARIN, T.; BOLAND, M.P. Oocyte and embryo quality: effect of origin, culture conditions and gene expression patterns. Reproduction Domestic Animal, v.38, p.259-267, 2003.

LOMBARDO, Y.B.; CHICCO, A.G. Effects of dietary polyunsaturated n-3 fatty acids on dyslipidemia and insulin resistance in rodents and humans. Review. Journal of Nutritional Biochemistry, v.17, p.1-13, 2006.

LU, K.H.; GORDON, I.; GALlAGHER, M.; MCGOVERN, H. Pregnancy established in cattle by transfer of embryos derived from in vitro fertilization of oocytes matured in vitro. Vet. Rec., v.121, p.259-260, 1987.

MARTINEZ, A.G.; MATOS, D.G.; FURNUS, C.C.; BROGLIATTI, G.M. In vitro evaluation and pregnancy rates after vitrification of in vitro produced bovine embryos. Theriogenology, v. 50, n. 5, p. 757- 767, 1998.

MASSIP A.; VAN DER ZWALMEN, P.; SCHEFFEN, B.; ECTORS, F. Some significant steps in the cryopreservation of mammalian embryos with a note on a vitrification procedure. Animal Reproduction Science, v. 19, p. 117 $129,1989$. 
MASSIP A.; MERMILLOD, P.; WILDS, C.; DESSY, F. Effects of dilution procedure and culture conditions after thawing on survival of frozen blastocysts procuced in vitro. Journal of Reproduction and Fertility, v. 97, p. 65- 69, 1993.

MASSIP A.; MERMILLOD, P.; DINNYES, A. Morphology and biochemistry of in vitro produced bovine embryos: implications for their cryopreservation. Human Reproduction, v. 10, nº 11, p. 3004- 3011, 1995.

MASSIP A.; MERMILLOD, P.; VAN LANGENDONKT, A.; REICHENBACH, H.D.; LONERGAN, P.; BERG, U.; CAROLAN, C.; DE ROOVER, R.; BREM, G. Calving outcome following transfer of embryos produced in vitro in different conditions. Animal Reproduction Science, v. 44, p. 1- 10, 1996.

MASSIP A. Cryopreservation of embryos of farm animals. Reproduction Domestic Animal, v. 36, p. 49- 55, 2001.

MAZUR, P. Slow-freezing injuries in mammalian cells. In: the freezing of mammalian embryos. Ciba Foundation, Symposium 52 (new series), p. 1948, Excerpta medica, Amsterdam, 1977.

MAZUR, P. Freezing of living cells: mechanisms and implications. American Journal Physiology, v. 247, p. 1442, 1984.

MAZUR, P.; LEIBO, S.P.; SEIDEL, G.E.Jr. Cryopreservation of the germplasm of animals used in biological and medical research: importante, impact, statys, and future directions. Biology Reproduction, v. 78, p. 2-12, 2008.

MERSMANN, A. Crystallization technology handbook. CRC Press, 832 pp, 2001. 
MERYMAN, H.T. Osmotic stress as a mechanism of freezing injury. Cryobiology, v. 8, p. 489-500, 1971.

MOORE, K.; RODRIGUEZ-SALLABERRY, C.J.; KRAMER, J.M.; JOHNSON, S.; WROCLAWSKA, E.; GOICOA, S.; NIASARI-NASLAJI, A. In vitro production of bovine embryos im medium supplemented with a serum replacer: Effects on blastocyst development, cryotolerance and survival to term. Theriogenology, v. 68, p. 1316- 1325, 2007.

MORRIS, G.J.; CLARK, A. Cells at low temperatures. In: The effects of low temperatures in biological systems. (editors BWW grout, GJ Morris). London: Edward Arnold, p. 72- 118, 1987.

NAGASHIMA, H.; KASHIWAZAKI, N.; ASHMAN, R.J.; GRUPEN, C.G.; SEAMARK, R.F.; NOTTLEN, M. Recent advances in cryopreservation of porcine embryos. Theriogenology, v. 41, p. 113- 118, 1994.

NAGASHIMA, H.; KASHIWAZAKI, N.; ASHMAN, R.J.; GRUPEN, C.G.; NOTTLEN, M. Cryopreservation of porcine embryos. Nature, p. 374- 416, 1995.

NIEMANN, H. Advances in cryopreservation of bovine oocytes and embryos derived in vitro and in vivo. "Reproduction and Animal Breeding: Advances and Strategies", 15 Symposium Int. Di Zootecnica, p. 117-128, 1995.

PALASZ, A.T.;MAPLETOFT, E.J. Cryopreservation of mammalian embryos and oocytes: recent advances. Biotechnology Advances, v. 14, n² 2, p. 127 $149,1996$.

PARIZA, M.W.; PARK, Y.; COOK, M.E. The biologically active isomers of conjugated linoleic acid. Progress in Lipid Research, v. 40, p. 283- 298, 2001 . 
PARK, Y.; STORKSON, K.J.; ALBRIGHT, K.J.; LIU, W.; PARIZA, M.W. Evidence that the trans-10,cis-12 isomer of conjugated linoleic acid induces body composition changes in mice. Lipids, v. 34, p. 235-241, 1999.

PARRISH, J.; SUSKO-PARRISH, J.; LEIBFRIED-RUTLEDGE, M.L.; CRISTER, E.S.; EYESTONE, W.H.; FIRST, N.L. Bovine in vitro fertilization with frozenthawed semen. Theriogenology, v. 25, n. 4, p. 591-600, 1986.

PEIXER, M.A.; SOUZA, R.V.; RUMP, R.; DE BEM, A.R.; NETO, M.A.P. Nascimento dos primeiros produtos de FIV da raça Nelore no Cenargem. Zootecnia, v. 32, p. 49, 1994.

PEREIRA, R.M.; BAPTISTA, M.C.; VASQUES, M.I.; HORTA, A.E.M.;PORTA, P.V.; BESSA, R.J.B.; MARQUES, C.C. Post-thawing resistance of bovine embryos is improved by trans-10; cis-12conjugated linoleic acid (CLA). Anais do $1^{\text {th }}$ International Congress on Animal Reproduction, Porto Seguro, Bahia, Brasil, 2004.

PEREIRA, R.M.; BAPTISTA, M.C.; VASQUES, M.I.; HORTA, A.E.M.;portugal, P.V.; BESSA, R.J.B.; CHAGAS E SILVA, J.; SILVA PEREIRA, M.; MARQUES, C.C. Cryo-survival of bovine blastocysts is enhanced by culture with trans10, cis-12 conjugated linoleic acid (10t, 12c CLA). Animal Reproduction Science, v. 98, p. 293-301, 2007.

PEREIRA, R.M.; CARVALHAIS, I.; PIMENTA, J.; BAPTISTA, M.C.; VASQUES, M.I.; HORTA, A.E.M.; SANTOS, I.C.; MARQUES, M.R.; REIS, A.; SILVA PEREIRA, M.; MARQUES, C.C. Biopsied and vitrified bovine embryos viability is improved by trans10, cis12 conjugated linoleic acid supplementation during in vitro embryo culture. Animal Reproduction Science, v. 106, p. 322-332, 2008a.

PEREIRA, R.M. and MARQUES, C.C. Animal oocyte and embryo cryopreservation. Cell Tissue Banking, v. 9, p. 267-277, 2008b. 
PETERSON, D.G.;MATITASHVILI, E.A.; BAUMAN, D.E. Diet-induced milk fat depression in dairy cows results in increase trans-10, cis-12 CLA in milk fat and coordinate suppression of mRNA abundance for mammary enzymes involved in milk fat synthesis. Journal of Nutrition, v. 133, p. 3098-3102, 2003.

PINYOPUMMINTR, T.; BAVISTER, B.D. In Vitro-Matured/in vivo-Fertilized bovine oocytes can develop into morulae/blastocysts in chemically defined, protein-free cultured media. Biology Reproduction, v. 45, p. 736-742, 1991.

PINYOPUMMINTR, T.; BAVISTER, B.D. Development of bovine embryos in a cell-free culture medium: effects of type of serum, timing of its inclusion and heat inactivation. Theriogenology, v. 41, p. 1241-1249, 1994.

POLGE, C.; SMITH, A.U.; PARKS, A.S. Revival of spermatozoa after vitrification and dehydratation at low temperatures. Nature, v. 164, p. 666, 1949.

POLLARD, J.W.; LEIBO, S.P. Comparative cryobiology of in vitro and in vivo derived bovine embryos. Theriogenology, v. 39, p. 287, 1993.

POLLARD, J.W.; LEIBO, S.P. Chilling sensitivy of mammalian embryos. Theriogenology, v. 41, p. 101-106, 1994.

RALL, W.F. Advances in the cryopreservation of embryos and prospects for the application to the conservation of salmonid fishes. Genetic Conservation of Salmonid Fishes, New York, 1992.

RAYOS, A.A.; TAKAHSI, Y.; HISHINUMA, M.; KANAGAWA, H. Quick freezing of one-cell mouse embryos using ethylene glycol with sucrose. Theriogenology, v. 37, p. 595-603, 1992. 
REIS, A.; MAcCALlUM, G.J.; McEVOY, T.G. Accumulation and distribution of neural lipid droplets is nom-uniform in ovine blastocysts produced in vitro in either the presence or absence of serum. Reproduction Fertility Development, v. 17, p. 815-823, 2005.

REIS, A.; McCALlUM, G.J.; STAINES, M.E.; EWEN, M.; LOMAX, M.A.; ROOKE, J.A. McEVOY, T.G. Vitamin E supplementation improves bovine embryo development in vitro. Reproduction, Abstract Series, v. 28, p.15-16, 2002.

REIS, A.; ROOKE, J.A.; McCALLUM, G.J.; EWEN, M.; STAINES, M.E. LOMAX, M.A. Fatty acid content of polar and neutral lipids from bovine blastocysts produced in vitro in the presence or absence of serum. Reproduction, p. 30, 2003 (abstr).

RICHARD, M.W.; SPTIZER, J.C.; WARNER, M.B. Effect of varying levels of postpartum nutrition and body condition at calving on subsequent reproductive performance in beef cattle. Journal of Animal Science, v. 62, n. 2, p. 300-306, 1986.

RIZOS, D.; CLEMENTE, M.; BERMEJO-ALVAREZ, P.; DE LA FUENTE, J.; LONERGAN, P.; GUTIÉRREZ-ADÁN, A. Consequences of in vitro culture conditions on embryos development and quality. Reproduction Domestic Animal, v. 43, p. 44-50, 2008.

RIZOS, D.; FAIR, T.; PAPADOPOULOS, S.; BOLAND, M.P.; LONERGAN, P. Developmental, qualitative, and ultrastructural differences between ovine and bovine embryos produced in vivo or in vitro. Molecular Reproduction Development, v. 62, p. 320-322, 2002.

RIZOS, D.; GUTIERREZ-ADAN, A.; PEREZ-GARNELO, S.; DE LA FUENTE, J.; BOLAND, M.P.; LONERGAN, P. Bovine embryo culture in the presence or the absence of serum: implications for blastocyst development, cryotolorance, 
and messenger RNA expression. Biology Reproduction, v. 68, p.236-243, 2003.

RIZOS, D.; WARD, F.; BOLAND, M.P.; LONERGAN, P. Effect of culture system on the yield and quality of bovine blastocysts as assessed by survival after vitrification. Theriogenology, v. 56, p. 1-16, 2001.

SATA, R.; TSUJII, H.; ABE, H.; YAMASHITA, S.; HOCHI, H. Fatty acid composition of bovine embryos cultured in serum-free and serum-containing médium during early embryonic development. Journal Reproduction Development, v. 45, p. 97-103, 1999.

SCHMITZ, G.; ECKER, J. The opposing effects of $n-3$ and $n-6$ fatty acids. Progress in Lipid Research, v. 47, p. 147-155, 2008.

SHAMSUDDIN, M.; RODRIGUEZ-MARTINEZ, H. Fine structure of bovine blastocyst developed either in serum free medium or in conventional coculture epithelial cells. Journal of Veterinar Medicine, v. 41, p. 307-316, 1994.

SEIDEL, G.E. Principles of cryopreservation of mammalian embryos. In: TECHNIQUES FOR FREEZING MAMMALIAN EMBRYOS, Colorado State, University. Proceedings... p. 7-14, 1984.

SEIDEL, G.E. Modifying oocytes and embryos to improve their cryopreservation. Theriogenology, v. 65, p. 228-235, 2006.

SEIDEL, G.E.; ELSDEN, R.P.; BRINK, Z. Cryopreservation of bovine embryos in media with chemically defined macromolecules. Theriogenology, v. 33, p. 322, 1990 (abstr). 
SOMMERFELD, V.; NIEMANN, H. Cryopreservation of bovine in vitro produced embryos using ethylene glycol in controlled freezing or vitrification. Cryobiology, v. 38, p. 95-105, 1999.

STEPTOE, P.C.; EDWARDS, R.G. Birth after the implatation of human embryo. Lancet, v. 2, p. 366, 1978.

STUBBS, C.D.; SMITH, A.D. The modification of mammalian membranes polyunsaturated fatty acid composition in relation to membrane fluidity and function. Biochemistry Biophys Acta, v. 137, p. 779-789, 1984.

SUZUKI, T.; YAMAMOO, M.; OOE, M.; SAKATA, A.; MATSUOKA, M.; NISHIKITA, M.; OKOMATO, K. Effect of sucrose concentration used for onestep dilution upon in vitro and in vivo survival of bovine embryos refrigerated in glycerol, and 1,2 propanodiol. Theriogenology, v. 34, p. 1051-1057, 1990.

TARIN, J.J.; TROUNSON, A.O. Effects of stimulation or inhibition of lipid peroxidation on freezing-thawing of mouse embryos. Biology Reproduction, v. 49, p. 1362-1368, 1993.

TAKAHASHI, M.; KEICHO, K.; TAKAHASHI, H.; OGAWA, H.; SCHULTZ, R.M.; OKANO, A. Effect of oxidative stress on development and DNA damage in vitro cultured bovine embryos by comet assay. Theriogenology, v. 54, p. 137-145, 2000.

TAKAHASHI, M.; SAKA, N.; TAKAHASHI, H.; KANAI, Y.; SCHULTZ, R.M.; OKANO, Assessment of DNA damage in individual hamster embryos by comet assay. Molecular Reproduction Development, v. 54, p. 1-7, 1999.

THOMPSON, J.G. Comparison between in vivo-derived and in vitro-produced pre-elongation embryos from domestic ruminants. Reproduction Fertility Development, v. 9, p. 341-354, 1997. 
THOMPSON, J.G. In vitro culture and embryo metabolism of cattle and sheep embryos - a decade of achievement. Animal Reproduction Science, v. 61, p. 263-275, 2000.

THOMPSON, J.G.; GARDNER, D.K.; PUGH, P.A.; MCMILLAN, W.H.; TERVIT, H.R. Lamb bird weight is affected by culture system utilized during in vitro pré-elongation development of ovine embryos. Biology Reproduction, v. 53, p. 1385-1391, 1995.

TOMINAGA, K.; HAMADA, Y.; YABUUE, T.; ARIYOSHI, T. Effect of linoleic acid-albumin on post-thaw survival of in vitro-produced bovine embryos at the 16 cell stage. Journal Veterinary Medicine Science, v. 62 (4), p. 465467, 2000.

TROUNSEN, A.; MOHR, L. Human pregnancy following cryopreservation, thawing and transfer of an eight-cell embryo. Nature, v. 305, p. 707, 1983.

USHIJIMA, H.; YAMAKAWA, H.; NAGASHIMA, H. Cryopreservation of bovine pre-morula-stage in vitro matured/in vitro fertilized embryos after delipidation and before use in nucleus transfer. Biology Reproduction, v. 60, p. 534-539, 1999.

USHIJIMA, H.; YPSHIOKA, H.; ESAKI, R.; TAKAHASHI, K.; KUWAYAMA, M.; NAKANE, T.; NAGASHIMA, H. Improved survival of vitrified in vivo-derived porcine embryos. Journal of Reproduction Development, v. 50, p. 481-486, 2004.

VAJTA, G.; HYTELL, P.; CALLESEN, H. Morphological changes of in vitro produced bovine blastocysts after vitrification, in straw direct reydration, and culture. Molecular Reproduction and Development, v. 48, n. 1, p. 9$17,1997$. 
VAN LANGENDOUCKT, A.; AUQUIER, P.; DONNAY, I.; MASSIP, A.; DESSEY, F. Acceleration of in vitro bovine embryo development in the presence of fetal calf serum. Theriogenology, v. 45, p. 194, 1996.

VAN LANGENDOUCKT, A.; DONNAY, I.; SCHUURBRIERS, N.; AUQUIER, P.; CAROLAN, C.; MASSIP, A.; DESSEY, F. Effects of supplementation with fetal calf serum on development of bovine embryos in synthetic oviduct fluid medium. Journal of Reproduction and Fertility, 109: 87-93, 1997.

VAN SOOM, A; MAHMOUDZADEH, A.R.; CHRISTOPHE, A.; YSEBAERT, M.T.; KRUIF, A. Silicone oil used microdrop culture an affect bovine embryonic development and freezability. Reproduction Domestic Animal, v. 36, p. 169-176, 2001.

VAN SOOM, A.; YUAN, Y.Q.; PEELMAN, L.J.; DE MATOS, D.G.; DEWULF, J.; LAEVENS, H.; DE KRUIF, A. Prevalence of apoptosis and inner cell allocation in bovine embryos cultured under different oxygen tension with ou without cysteine addition. Theriogenology, v. 57, p. 1453-1465, 2002.

VARISANGA, M.D.; DONG, Y.J.; MTANGO, N.R.; SUZUKI, T. Comparison of the effets of using standard and simple portable $\mathrm{CO}_{2}$ incubators on the in vitro developmental competence of bovine embryos reconstituted by somatic cell nuclear transfer. Theriogenology, v. 58, p. 77-86, 2002.

VERLENGIA. R.; GORJÃO; R.; KANUNFRE, C.C.; BORDIN, S.; DE LIMA, T.M.; MARTINS, E.F.; CURI, R. Comparative effects of eicosapentaenoic acid and docohexaenoic acid in proliferation, cytokine production, and pleitropic gene expression in Jurkat cells. Journal Nutritional Biochemistry, v.15, p.657-665, 2004.

VOECKEL, S.A.; HU, Y.X. Use of ethylene-glycol as a cryoprotectant for bovine embryos allowing direct transfer of frozen-thawed embryos to recipient females. Theriogenology, v.3, p.687-697, 1992. 
WATANABE, M.R.; WATANABE, Y.F.; PERIPATO, A.C.; VILA. R.A.; FIRMINO, F.; NOGUEIRA, M.F.G.; PUPIM, F.P.V.; LOBO, R.B. Taxa de prenhez de embriões bovinos produzidos in vitro após vitrificação. Arq. da Fac. de Med. Vet., UFRGS, Porto Alegre-RS, v. 24, p. 264, 1996.

WATANABE, Y.F.; OLIVEIRA FILHO, E.B.; QUETGLAS, M.D.; GARCIA, J.M.; NOGUEIRA, M.F.G.; SILVA FILHO, I.R.; VANTINI, R. Desenvolvimento de gestação em bovinos com embriões produzidos em programa de fecundação in vitro. ARS Veterinária, v. 2, p. 191, 1993.

WATANABE, Y.F.; WATANABE, M.R.; GALERANI, M.A.V.; VILA, R.A.; LOBO, R.B. The influence of $\mathrm{B} 2$ and a modified $\mathrm{CR}-2$ medium on the in vitro production of bovine embryos with cumulus and oviduct co-culture. Theriogenology, v. 51, p. 251, 1999.

WHITTINGHAM, D.G. Survival of mouse embryos after frezing and thawing. Nature, v. 233, n. 5315, p. 125-126, 1971.

WHITTINGHAM, D.G. Symposium on freezing of ova and embryos-synopsis papers. Freezing embryos of laboratory species. Cryobiology, v. 15, p. 367369, 1978.

WILMUT, I.; ROWSON, L.E.A. Experiments on the low-temperature preservation of cow embryos. Veterinary Record, v. 92, n. 26, p. 686-190, 1973.

WRENZYCKI, C.; HERRMANN, D.; KESKINTEPE, L.; MARTINS, A.J.R.; SIRISATHIEN, S.; BRACKETT, B.; NIEMANN, H. Effects of culture system and protein supplementation on mRNA expression in pre-implantation bovine embryos. Human Reproduction, v. 13, p. 998-901, 2001. 
ZERON, Y.; PEARL, M.; BOROCHOV, A.; ARAV, A. Kinetic and temporal factors influence chilling injury to germinal vesicle and mature bovine oocytes. Cryobiology, v. 38, p. 35-42, 1999.

ZERON, Y.; OCHERETNY, A.; KEDAR, O.; BOROCHOV, A.; SKLAN, D.; ARAV, A. Seasonal changes in bovine fertility: relation to developmental competence of oocytes, membrane properties and fatty acid composition of follicles. Reproduction, v. 121, p. 447-454, 2001.

ZERON, Y.; SKLAN, D.; ARAV, A.. Effect of polyunsaturated fatty acid supplementation on biophysical parameters and chilling sensitivy of ewe oocytes. Molecular Reproduction Development, v. 61, p. 271-278, 2002. 